WSRC-TR-2004-00148

Groundwater Strategy for the OU-1 Landfill Area, Miamisburg Closure Project, Ohio

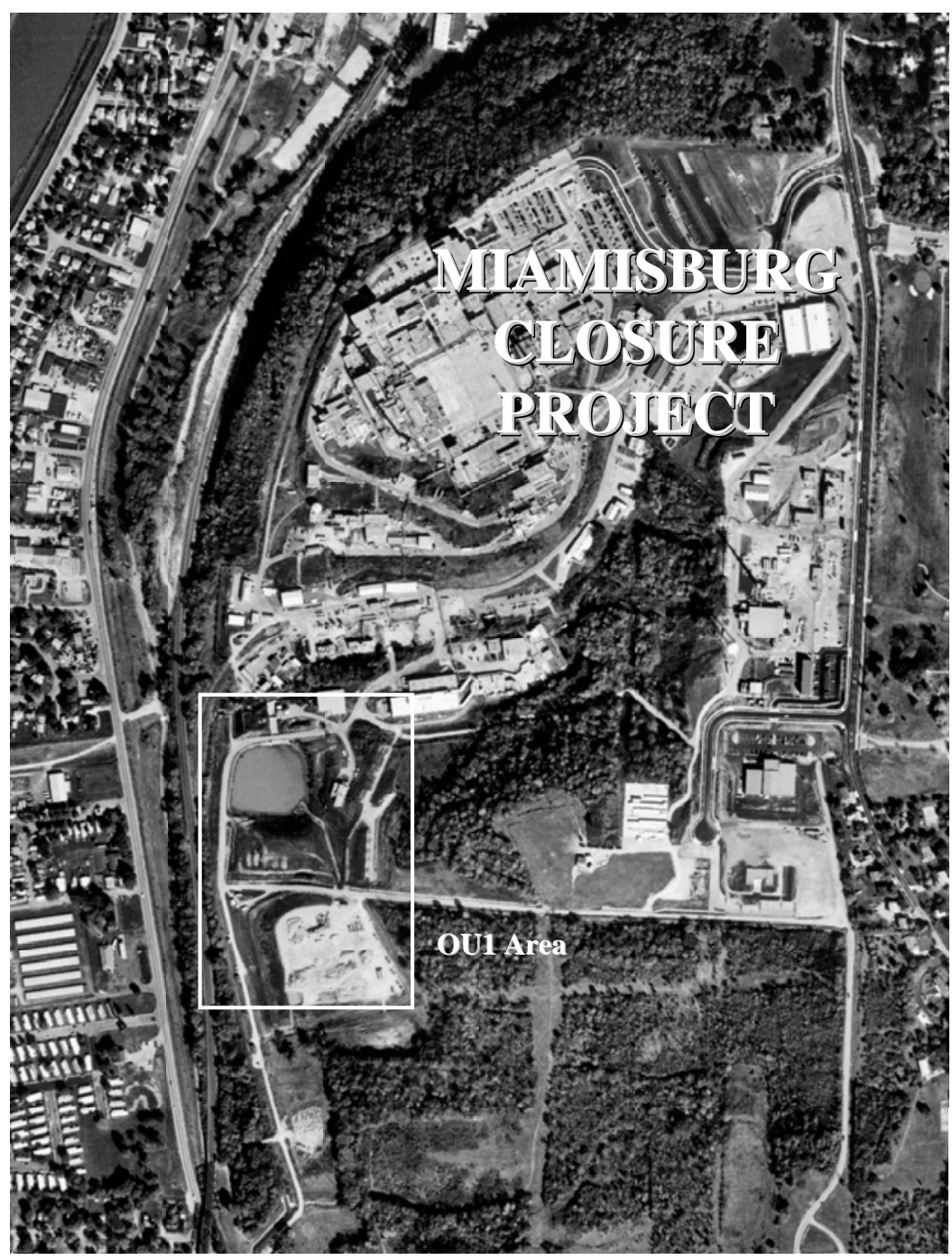

DOE Technical Assistance Panel

Miamisburg, Ohio

January 20-22, 2004 
This document was prepared in conjunction with work accomplished under Contract No. DE-AC09-96SR18500 with the U. S. Department of Energy.

\section{DISCLAIMER}

This report was prepared as an account of work sponsored by an agency of the United States Government. Neither the United States Government nor any agency thereof, nor any of their employees, makes any warranty, express or implied, or assumes any legal liability or responsibility for the accuracy, completeness, or usefulness of any information, apparatus, product or process disclosed, or represents that its use would not infringe privately owned rights. Reference herein to any specific commercial product, process or service by trade name, trademark, manufacturer, or otherwise does not necessarily constitute or imply its endorsement, recommendation, or favoring by the United States Government or any agency thereof. The views and opinions of authors expressed herein do not necessarily state or reflect those of the United States Government or any agency thereof.

This report has been reproduced directly from the best available copy.

Available for sale to the public, in paper, from: U.S. Department of Commerce, National Technical Information Service, 5285 Port Royal Road, Springfield, VA 22161, phone: (800) 553-6847, fax: (703) 605-6900

email: orders@ntis.fedworld.gov

online ordering: http://www.ntis.gov/help/index.asp

Available electronically at http://www.osti.gov/bridge

Available for a processing fee to U.S. Department of Energy and its contractors, in paper, from: U.S. Department of Energy, Office of Scientific and Technical Information, P.O. Box 62, Oak Ridge, TN 37831-0062,

phone: (865)576-8401,

fax: (865)576-5728

email: $\underline{\text { reports@ adonis.osti.gov }}$ 
U. S. Department of Energy

\title{
Groundwater Strategy for the OU-1 Landfill Area, Miamisburg Closure Project, Ohio
}

\section{Miamisburg OH, January 20-22, 2004}

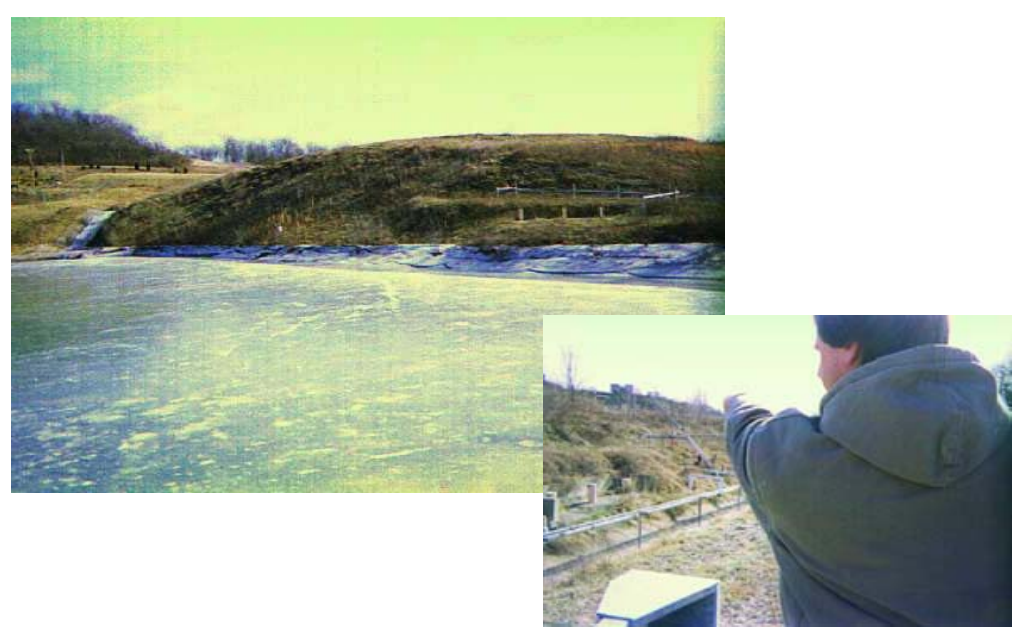

Technical Assistance Team / Authors:

\author{
Brian B. Looney ${ }^{1}$ (chair) \\ Terry C. Hazen ${ }^{2}$ \\ Charles J. Newell ${ }^{3}$. \\ Miles E. Denham ${ }^{1}$ \\ Brian D. Riha ${ }^{1}$ \\ Carol Eddy-Dilek ${ }^{1}$
}

${ }^{1}$ Savannah River Technology Center, Aiken SC

${ }^{2}$ Lawrence Berkeley National Laboratory, Berkeley CA

${ }^{3}$ Groundwater Services Inc, Houston TX 


\section{Acknowledgements:}

The team acknowledges the support of the Jef Walker of the U. S. Department of Energy Technical Solutions Program; Paul Lucas and Danny Punch of the Miamisburg Closure Project; and Debbie White of Ohio DOE for their support. The team would like to express particular appreciation the CH2MHill project personnel including Joyce Massie who provided logistical and technical support and to Mark Gilliat and Dick Neff who provided the data requested by the team and provided sufficient background information to allow our effort to be efficient and effective. 


\title{
Groundwater Strategy for the OU-1 Landfill Area, Miamisburg Closure Project, Ohio
}

\author{
Contents

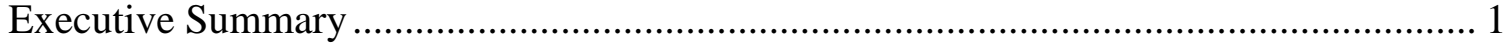

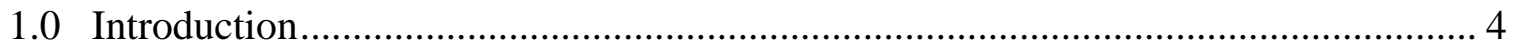

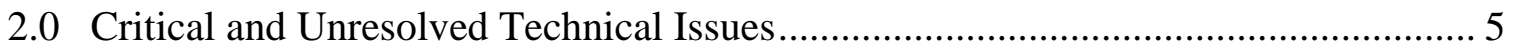

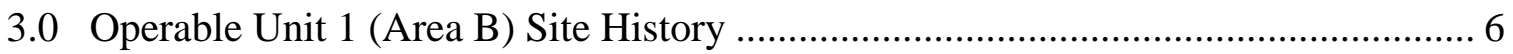

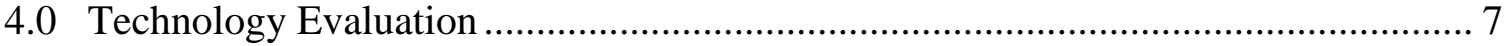

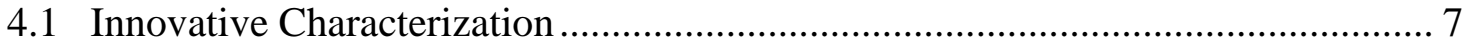

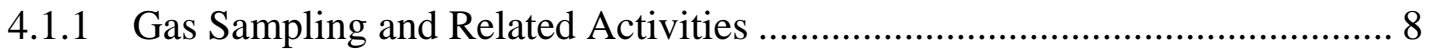 \\ 4.1.2 Characterization Approach ......................................................................... 8 \\ 4.1.3 Presence/Absence of DNAPL .............................................................. 9 \\ 4.1.4 VOC Rebound Test for Mass Transfer Rates ........................................... 10 \\ 4.2 Hydrology_Determination of Critical and Controlling Factors ......................... 15

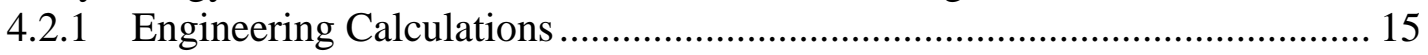

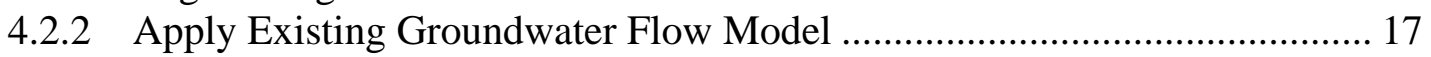

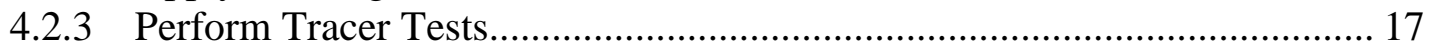 \\ 4.3 Attenuation Rates and Response to Amendments ......................................... 18

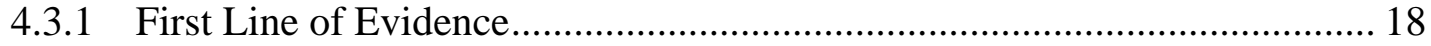 \\ 4.3.2 Second Line of Evidence ........................................................................ 27

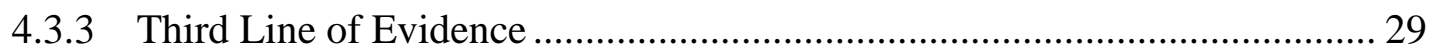 \\ 5.0 Site Management, Remediation and Configuration ............................................. 41

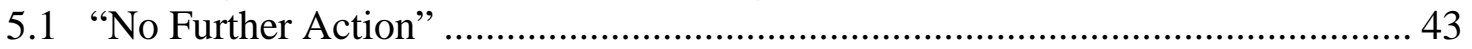 \\ 5.2 Continued operation of SVE (Vadose zone source) ......................................... 44 \\ 5.3 Continue Operation of groundwater P\&T (Groundwater source) ........................ 44 \\ 5.4 Monitored Natural Attenuation........................................................................ 45

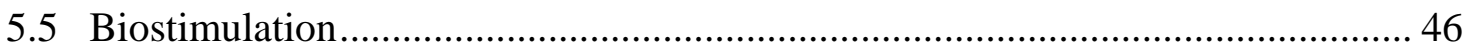

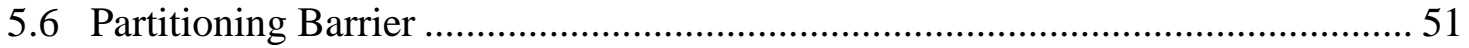

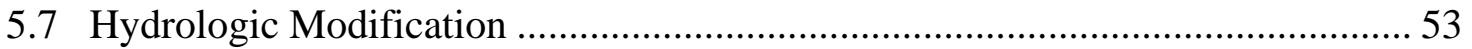

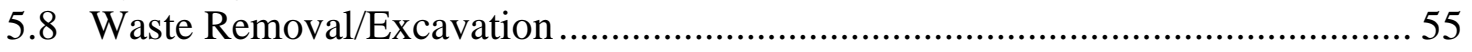

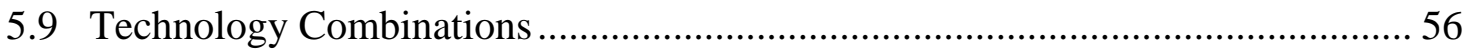

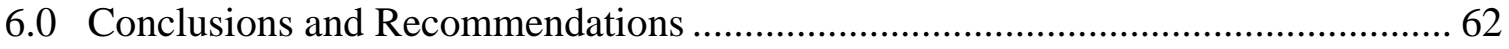




\section{“blank page”}




\section{EXECUTIVE SUMMARY}

The general objective of the study was to assist the Miamisburg Closure Project (MCP) in their efforts to develop and refine a comprehensive, technically sound strategy for remediation of groundwater contaminated with trichloroethylene (TCE) and other volatile organic compounds (VOCs) in the vicinity of the landfill in Operable Unit 1. To provide the necessary flexibility to the site, regulators and stakeholders, the resulting evaluation considered a variety of approaches ranging from "no further action" to waste removal. The approaches also included continued soil vapor extraction (SVE), continued groundwater pump and treat (P\&T), monitored natural attenuation (MNA), biostimulation, partitioning barriers, hydrologic modification, and others.

The technical assistance team consisted of a diverse group of nationally recognized experts with expertise in hydrogeology, geochemistry, characterization, microbiology, remediation, dense non-aqueous phase liquids (DNAPLs) and natural attenuation. A principal consensus of the technical assistance team was that the concentrations of VOC in the groundwater underlying OU-1 are low (generally less than 20 to $30 \mu \mathrm{g} / \mathrm{L}$ (ppb) even after a period of rebound following SVE and P\&T). The team agrees that these levels of VOCs in the groundwater in this setting pose minimal risk. Thus the team believes that the aggressiveness of the response action should be balanced and appropriate to the low concentrations at the site. Each of the individual remediation technologies examined by the team had positives and negatives, but none was ideal when used alone. Instead, a few combinations of technologies emerged as promising. Typically, the groupings of promising technologies consisted of limited action directed at the low levels of residual VOC being released into soil and groundwater ("sources" that remain after groundwater P\&T and SVE), supplemented by natural attenuation, monitoring and leading toward no further action.

Several critical and unresolved issues were identified by the team. Two notable and overarching issues were: 1 ) the need to examine the various OU-1 activities in an integrated fashion and develop consistent and synergistic strategies for planned actions at the multiple identified potential release sites (PRSs), and 2) The need to account for potential system changes when evaluating long term performance of selected technologies. An example of a system change with significant impacts that propagate through a wide range of potential actions is the modification or elimination of production well pumping. Elimination of pumping in the OU-1 area production wells will shift the groundwater flow patterns (direction and rate), the plume shape, and the performance of groundwater remediation and management systems. Additionally the team recommended that an additional characterization effort is needed to identify potential VOC sources both upgradient of the landfill and below the cocooned debris. 
A large number of data needs and uncertainties were also identified in the issues section. Using a technology matrix approach, the team then developed rapid and relatively low cost characterization recommendations to address the most critical data needs and uncertainties. There were several notable characterization and monitoring recommendations. The team recommended a suite of innovative approaches based on soil gas concentrations and rebound tests in a variety of locations. As with the other characterization recommendations each element of the soil gas suite was formulated as an objective/hypothesis and the resulting data is intended to prove or disprove the hypothesis. For instance, to address the hypothesis that there is (or is not) significant VOC present within the isolated waste "cocoon", the team proposed extracting gas from the dry drain line that penetrates the clay barrier. The resulting data would provide an inexpensive direct and relatively robust hypothesis test. Other notable items in the characterization recommendations include focused data collection, primarily the multiple lines of evidence developed by USEPA, to assess natural attenuation potential. A large number of other characterization tools were examined in the technology matrix. Some of these were recommended and some were "not recommended".

Depending on the characterization results, the team identified several technologies that should be considered in a preliminary sense as viable for addressing OU-1 VOC target(s). This process also used a technology matrix. The resulting viable technologies include SVE, P\&T, MNA, biostimulation/partitioning barrier, and hydrologic modification. Some of these may not be justified if the data indicate that source VOC has been effectively addressed by previous efforts (e.g., continued P\&T or continued SVE). "No further action” was considered a longer term end-state goal of other actions rather than a near term strategy. Large scale waste removal, while viable, was generally not recommended. To provide insight into the workings of the team, the paragraphs below summarize some of the deliberations for two widely different example technologies - first MNA and then aggressive technologies such as large scale waste removal.

MNA example -- The measured VOC concentrations in the groundwater underlying OU-1 are less than about $98 \%$ of the sites reported in a recent survey of sites that are utilizing MNA for remediation. Low concentrations alone however are insufficient technical justification for natural attenuation. Disciplined and responsible MNA requires multiple lines of evidence as specified by the U.S. Environmental Protection Agency in their protocols and directives. In fact, while the team found evidence that natural attenuation processes have occurred at the OU-1 site, the data suggest that the processes may not be sufficient to adequately address the plume and supplemental approaches are likely to be required. The data suggest that operation of P\&T and SVE may negatively impact natural attenuation processes by accelerating the flow of competing electron acceptors into the "source." Data on plume concentrations as a function of time, the presence and depletion of beneficial electron donor, natural sulfate from aquifer minerals and other issues provide insight about the viability and role of MNA and the potential to supplement MNA with targeted biostimulation.

Aggressive technology example -- Aggressive in situ technologies, such as thermal methods and in situ chemical destruction, were deemed to be inappropriate and were not evaluated they are costly and implementation of the technology itself has concomitant risks and potential for collateral damage that are significant relative to the original contamination. The 
most aggressive technologies evaluated, including large-scale waste removal, were not recommended (even in combination with other approaches) because they are not appropriate to the low concentrations at the site. While a removal action would not pose a risk of significant contaminant release, it would be more costly than alternatives with similar effectiveness and would pose worker and transportation risk and provide minimal potential offsetting benefit.

Based on the current characterization data and the performance characteristics of the available remediation alternatives, the team feels that a single technology will not be appropriate to address residual contamination at the OU-1 landfill. Instead, the team recommends that the site consider combining several technologies to provide a robust solution. Several groupings of promising technologies are presented that use appropriate level of response to address the relatively low levels of residual VOC being released into soil and groundwater ("sources" that remain after groundwater P\&T and SVE), supplemented by natural attenuation, monitoring and leading toward no further action. The additional characterization work will provide the basis to select the appropriate combination of technologies. 


\subsection{INTRODUCTION}

This report presents the results of a technical assistance workshop held at the Miamisburg Closure Project that met in January 2004. This workshop focused on development of a plan to evaluate and select a long-term strategy for closure of the OU-1 landfill and address VOCs in the soil and groundwater in the vicinity of this landfill. Prior to the initiation activities at the Mound Plant in 1947, the OU- 1 landfill area consisted of a depression produced from old gravel operations. During following years of operations at the site, this area was used for disposal of trash, laboratory waste and other wastes. VOC's were identified in groundwater and remedial actions were initiated in 1997. Identification and removal of contaminant sources was coupled with active groundwater treatment of solvents (air sparging and soil vapor extraction). The active source treatment activities were terminated in May 2003 in order to evaluate the performance of the active remedial systems through continuing rebound testing. Solvent contamination, primarily trichloroethylene (TCE), is still present at very low levels in some groundwater samples collected during the rebound test.

The technical assistance was conducted to support the DOE Ohio Field Office, the site contractor CH2MHill, the Ohio Environmental Protection Agency (OEPA), the Miamisburg Community Improvement Corporation (MMCIC) and other Miamisburg Closure Project Stakeholders. Funding support was provided by the Department of Energy (DOE) Office of Science and Technology Closure Site Technical Assistance Program. The Technical Assistance Team included professionals with expertise in the fields of geology, geochemistry, microbiology, Monitored Natural Attenuation (MNA), and environmental characterization and remediation. Also participating in the workshop were personnel from the site remediation contractor (CH2MHill), the DOE Ohio field office, and regulatory personnel from OEPA. 


\subsection{CRITICAL AND UNRESOLVED TECHNICAL ISSUES}

Critical Technical Issues identified by the Technical Solutions Team included the following:

- Impacts of changing conditions and propagation of those impacts in long-term management and configuration of OU-1 area. Of particular note are the potential impacts of modified hydrologic conditions and production well pumping.

- Integration of VOC activities into related OU-1 area plans - look for beneficial and synergistic opportunities to blend VOC response to nearby PRS plans (e.g., drum and soil removal actions, basin response actions, etc.) Consider opportunities to define an overarching, or comprehensive, strategy and ultimate configuration for the OU-1 area.

- Examine potential sources of VOC in the vicinity (upgradient and beneath of the cocooned debris) - the team particularly noted the presence of upgradient VOCs. Consider the potential that clay sediments excavated beneath the former burn cage are incorporated into cocoon liner.

Unresolved Technical Issues and Data Needs

The team identified a range of unresolved issues and areas that require more data to support management and decision-making at the site. These included:

- Resolving uncertainty in the spatial and temporal concentration of electron donors and electron acceptors.

- Further evaluating the original levels of contaminants and the impacts of past remediation

- Determining the impacts of the flux of sulfate entering BVA from bedrock system and the impact of fluxes from buried debris (e.g., iron, carbon, etc.)

- Interpreting and data mining historical concentrations in soil gas and vapor extraction system

- Assessing the implication of pumping production wells and assessing past pumping rates and histories and proposed changes.

- Estimating attenuation capacity and rates, and pore volumes treated by SVE and groundwater pumping.

- Performing follow-up evaluation of attenuation capacity using a walk through of the EPA protocol and multiple lines of evidence. This includes:

- General resolution of uncertainties in the various attenuation mechanisms and multiple lines of evidence (e.g., sorption properties)

- Perform natural attenuation modeling using EPA screening models such as BIOCHLOR if appropriate. 


\subsection{Operable Unit 1 (Area B) Site History}

Disposal of waste in Area B began in 1948 and disposal varied in nature and quantity throughout the history of Area B. An excellent summary of the history of Area B is documented in "Area B, Operable Unit 1 DOE Mound Plant - History of Area B" (Reference). Some highlights of this history are presented here.

- Prior to 1947 - residential area

- 1948 - 1954 -solid and liquid wastes disposed, mostly paper, glass, wood, plastics, kitchen garbage, urinalysis samples

o quantities disposed were relatively small

- 1954 - 1969 - variety and quantity of waste disposal expanded

o liquid wastes included solvents, oils, and chemicals

- burned by dumping on ground or stacking containers

- possible quantity 15,000 to 30,000 gallons

0 solid wastes mostly paper and kitchen garbage

- burned to reduce volume

- steel and metal debris disposed in trench

- 1954-1956 2500 empty crushed drums that had contained thorium disposed by burial near road to south

- 1950 s through 1997 - operated production wells along western road with typical pumping rates of 300 to $800 \mathrm{gpm}$

- 1969 - open burning banned

o hazardous liquid wastes sent offsite

o solid wastes disposed in trenches - paper, plastic, glass, cloth, kitchen garbage, plastic vials containing urine samples and scintillation fluids

- 1977-1978 - overflow pond and landfill constructed

o landfill contained material excavated to construct overflow pond

- approximately 100,000 cubic yards

- 4-5 foot thick clay liner beneath landfill, clay berms surround

- leachate drains installed in landfill, leachate directed to overflow pond

- 5 French drains installed below liner to ensure slope stability

- 1997 to 2003 - operated soil vapor extraction system. Operated a groundwater capture (pump and treat) system using 3 extraction wells to the south and a typical additional groundwater flow rate of $100 \mathrm{gpm}$

- 2003 to present - turned off SVE and P\&T systems and monitored rebound 


\subsection{TECHNOLOGY EVALUATION}

Two technology matrices were prepared to support the evaluation. The first to identify and compare viable technologies for characterization of the residual contamination and the second to compare alternative remedial and management strategies. In each technology matrix, the key aspects and issues for each technology are provided relative to site specific goals and the baseline remedial strategy. A description of criteria used to compare the technologies or approaches is listed below.

The technologies are evaluated based on the following criteria: Strategy, Effectiveness, Regulatory and Public Acceptability, Implementability/Sensitivity, Health and Safety Issues, Schedule, Cost, Technical Maturity, and Viability. Each of these criteria is described below:

- The Objective column describes the appropriate technical application for a given technology.

- The Effectiveness column describes how site specific technical conditions such as permeability or lithology may impact remedial performance and the sensitivity of the technology to measure contaminants at MCLs.

- Regulatory and Public Acceptability provides an assessment based on previous experience with similar sites

- Implementability identifies considerations associated with site logistics, health and safety issues, footprint needs, etc.

- Schedule

- Cost estimates the cost of implementation of the technology.

- Long term performance addresses residual risks and ability to reach cleanup objectives in a reasonable time frame

- Technical Maturity describes the state of development ranging from research to commercially available

In the last column, the technology is given an Overall ranking as either viable or not viable for this site application along with specific recommendations regarding application of this technology at this site. A brief synopsis of the identified technologies are provided below and the two technology matrices are provided at the end of the relevant sections.

\subsection{Innovative Characterization}

The primary goal of any additional sampling at a site with a significant amount of previous investigation should be to resolve uncertainties and provide specific information that will support responsible environmental decision making. Where possible technologies or approaches that address multiple uncertainties using innovative or integrated sampling campaigns should be considered.

Some of the general categories of uncertainties that the team considered related to the strength and location of residual VOC sources, natural attenuation rates and responses, and 
hydrology. After discussing individual technologies, the team brainstormed a variety of integrated sampling campaigns. These included:

- Gas Sampling; sampling the isolated debris, sampling beneath and around the cocoon, extending boreholes to the base of the BVA with depth discrete sampling, analytes and objectives

- Hydrology - Determination of Critical and Controlling Flows; includes tracer tests, geotechnical "engineering” analysis, modeling, etc.

- Attenuation Rates and Responses to Amendments;

\subsubsection{Gas Sampling and Related Activities}

VOC compounds were probably released at or near the surface at the burning cage area (now the overflow pond) and possibly from materials deposited with the landfill materials. The objectives of the additional characterization activities are:

- to search for unidentified VOC source areas,

- to investigate the source of groundwater concentration rebound (is the groundwater rebound only due to sorbed phase in the saturated zone?)

- to verify the performance of remediation activities,

- and to evaluate the natural attenuation capacity and mechanisms using cost-effective field screening and sampling methods.

A list of suggested analytes for specific sample media is provided in Table 1 and locations for additional characterization borings is provided on the map in Figure 4.1.

\subsubsection{Characterization Approach}

In order to reduce the uncertainty due to the presence of unidentified source areas, the team recommends a sampling campaign based on collection of soil gas samples from existing access points to the subsurface.

- Gas samples should be collected from inside the cocooned landfill material by pulling gas from the leachate collection pipe. Measure VOC gas concentrations, methane, carbon dioxide, and oxygen concentrations to determine VOC source risk inside the cocoon and natural attenuation mechanisms. If VOCs are present in appreciable concentrations, perform respirometry and mass transfer studies to determine natural attenuation rates and the release rate of VOCs to the soil gas. Finally, if justified, any VOCs identified within the cocoon can be easily remediated by a short period of SVE using the same access (the leachate collection pipe).

- Collect gas from the existing vapor extraction wells and French drains by starting the SVE system and collecting gas from each well as quickly as practical. The VOC measurements will provide the rebound concentration at equilibrium and can be used to evaluate vadose zone remediation progress by comparing shutdown and rebound VOC concentrations. In addition, ratios of VOC and breakdown products can be compared 
between shutdown and rebound concentrations to evaluate recovery of natural attenuation processes. The natural attenuation processes were likely degraded during the SVE and air sparging by introducing oxygen into the vadose zone. If VOCs are present in appreciable concentrations, perform respirometry and mass transfer studies to determine natural attenuation rates and the release rate of VOCs to the soil gas.

- Conduct direct pushes on the south side of the overflow pond (between the pond and the landfill) to evaluate the presence of additional VOC source areas (burn cage area and area below the cocoon). Collect soil gas at an approximate elevation of $690 \mathrm{ft}$ in the glacial outwash formation in the vadose zone (Figure 4.2). This zone is below the fine grain zones that could be a long-term source for the slow release of solvents. Maximize soil gas flow and zone of capture to help identify source areas under the current overflow pond (burn cage) and previous landfill areas. This can be accomplished by using a high capacity vacuum pump and pulling soil gas directly through the push rods using a sacrificial tip. Additional push locations are suggested as shown on Figure 4.1 to address other possible source areas associated with the old landfill area and old burial trench on the south side of the landfill. Site personnel should choose specific characterization locations.

- During the direct pushes, collect depth discrete water samples through the BVA. This task will rule out and/or identify additional sources to the groundwater. Groundwater depth profiling through the BVA will provide specific information to assess or rule out high concentration source lenses within the aquifer. If information is desired in low permeability zones, soil samples can be collected for VOC analysis. If zones of high concentrations are observed, tests and/or calculations to determine the significance of the source can be performed. In addition of VOCs, analyze for dissolved oxygen, redox potential, sulfate, nitrate, organic carbon, and ortho-phosphate. If contamination is measured and future monitoring is desired, small diameter prepacked wells can be installed very easily using direct push methods.

- Vadose zone pore water concentrations can be calculated based on Henry's Law equilibrium to evaluate a vadose zone source as the cause of groundwater concentration rebound in monitoring wells. Soil gas can be analyzed for carbon dioxide, oxygen, and methane to evaluate biodegradation and natural attenuation capacity in and below the landfill area. Respirometry and VOC rebound testing can be conducted to evaluate electron donor capacity and VOC mass transfer release rates.

\subsubsection{Presence/Absence of DNAPL}

As noted in the executive summary and conclusion sections of this report, "a principal consensus of the technical assistance team was that the concentrations of VOC in the groundwater underlying OU-1 are low (generally less than 20 to $30 \mu \mathrm{g} / \mathrm{L}$ (ppb) even after a period of rebound following SVE and P\&T)." Current and historical groundwater concentrations from monitoring wells do not indicate DNAPL in the BVA. Using a rule of thumb of $1-10 \%$ of solubility to indicate DNAPL (Cohen and Mercer) would require groundwater concentrations of approximately 1,500 to 15,000 $\mu \mathrm{g} / \mathrm{L}$ PCE (and even higher 
concentrations for TCE and the other solvents). In fact, the highest historical OU-1 PCE concentrations were $<500 \mu \mathrm{g} / \mathrm{L}$ and current OU-1 groundwater concentrations for PCE in the BVA are $<50 \mu \mathrm{g} / \mathrm{L}$. These concentrations are $<0.3 \%$ and $<0.03 \%$ of PCE solubility, respectively, and are far below concentrations that could be exist in groundwater in the presence of substantive DNAPL pools below the water table. Importantly, the wells installed in the BVA appear to target possible DNAPL flow paths along the top of the silty layers and bedrock as water moves away from the landfill area. The data clearly indicate that there is no potential for the presence of DNAPL pools below the water table and thus no potential offsite migration of mobile DNAPL phase solvent. The original disposal ("by dumping"), available soil data, and data collected during soil vapor extraction indicate that there is some residual contamination in the vadose zone (most likely associated with the slow release from finegrained sediments). Based on an assessment of these data, the team recommended a limited set of targeted characterization activities to address residual contamination (including DNAPLs) both in the vadose zone and groundwater. These recommendations are documented on the characterization technology matrix and consist of extending Geoprobe sampling through the entire depth of the BVA, vadose gas and soil sampling and rebound sampling.

\subsubsection{VOC Rebound Test for Mass Transfer Rates}

If VOC contamination is found in the vadose zone or cocoon, mass transfer relationships are beneficial to evaluate the rate of release of the source to groundwater. The VOC loading will need to be balanced by the appropriate treatment method(s). A test is proposed to measure a field mass transfer factor by injecting clean air into the subsurface through a sample port or well and measuring the rebound VOC concentration over time. The anticipated results of the tests will provide a mass transfer rate that will be used to estimate the source loading and can guide the appropriate type of remedial action (passive, enhanced or active) and possibly estimate the time frame for meeting the remedial objectives.

\subsubsection{Theory}

After displacement of VOC gas phase from a volume of sediments in the vadose zone, the gas concentration rebound is a field measure of the mass transfer of VOCs from the sorbed and dissolved phases and by gas diffusion from fine grain zones. This test is an adaptation of the in situ respiration tests used to evaluate bioventing by measuring the usage of oxygen in the subsurface over time (EPA 1995). The mass transfer factor (mass of contaminant per mass of soil per time) is a function of moisture content, porosity, and VOC concentration and provides a measure of the rate of release and thus the expected rate of removal for

$$
k_{f, c}=\frac{k_{c} \theta_{a}}{\rho_{b}}
$$

remediation. The field mass transfer function for contaminant $c\left(k_{f, c}\right)$ is described by the following equation:

where

$k_{f, c}=$ field mass transfer factor for compound $c\left(\mathrm{M}_{\mathrm{c}} / \mathrm{M}_{\mathrm{soil}} / \mathrm{T}\right)$

$k_{c}=$ compound concentration change rate $\left(\mathrm{M}_{\mathrm{c}} / \mathrm{L}^{3} / \mathrm{T}\right)$ 


$$
\begin{aligned}
\theta_{a} & =\text { gas filled porosity } \\
\rho_{b} & =\text { soil bulk density }\left(\mathrm{M}_{\text {soil }} / \mathrm{L}^{3}\right)
\end{aligned}
$$

\subsubsection{Procedure}

1. Measure initial gas concentrations.

2. Inject clean air into the vadose zone around the sampling point to displace VOC gas phase.

3. Collect gas samples over time while minimizing sample volume to avoid advective movement of VOC gas phase from surrounding sediments.

Table 4-1. Sample Type and Suggested Analytes

\begin{tabular}{|l|l|}
\hline Sample Type & Analytes \\
\hline Gas & VOCs and breakdown \\
& products \\
& Methane \\
& Carbon Dioxide \\
& Oxygen \\
\hline Water & VOCs and breakdown \\
& products \\
& Dissolved Oxygen, redox \\
& potential, sulfate, nitrate, \\
& organic carbon, and ortho- \\
& phosphate \\
\hline Soil & VOCs and breakdown \\
& products \\
& Organic Carbon \\
\hline
\end{tabular}




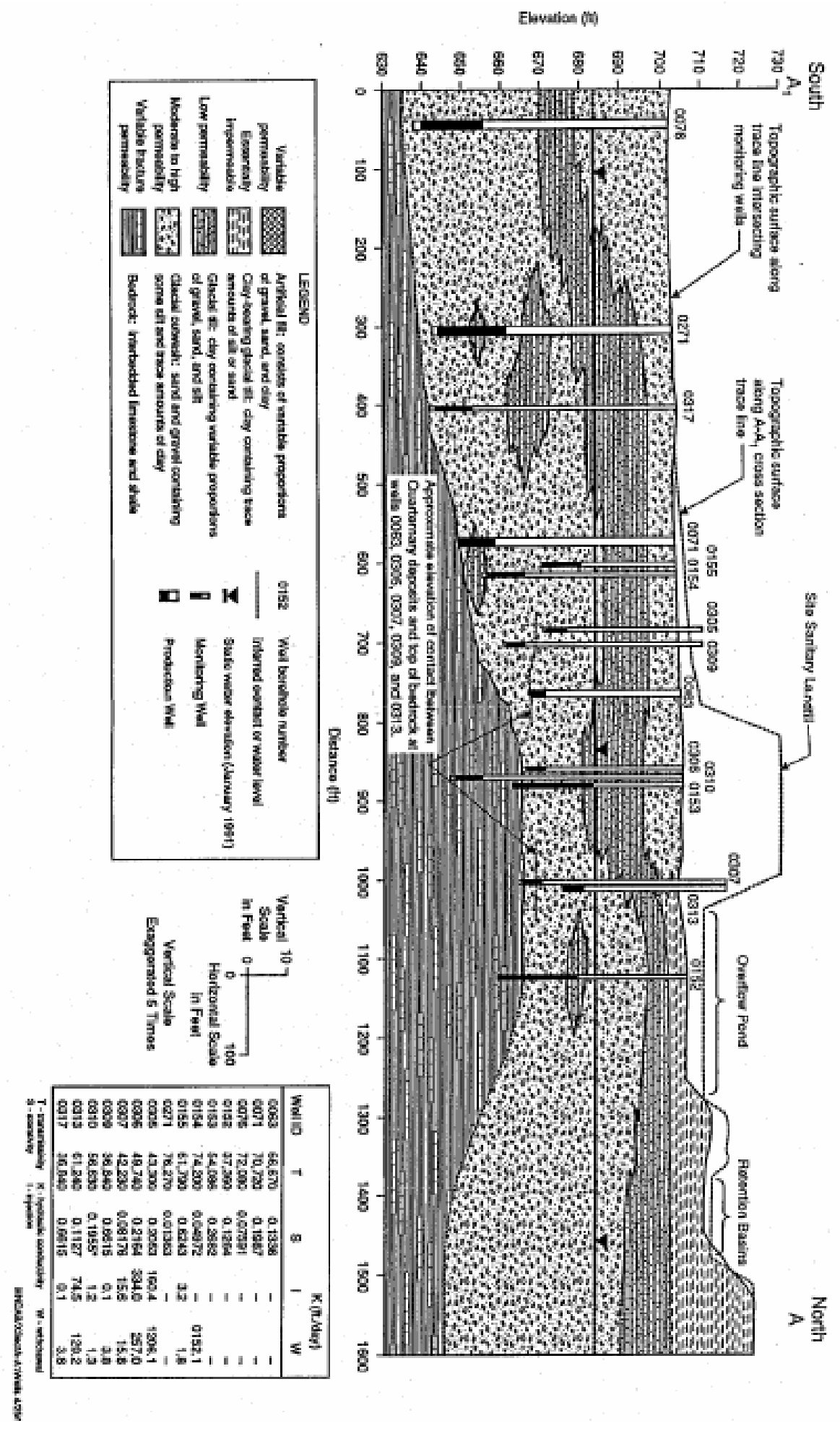

Figure 4-1. Suggested locations for large volume soil gas collection to evaluate source areas under the overflow pond. 


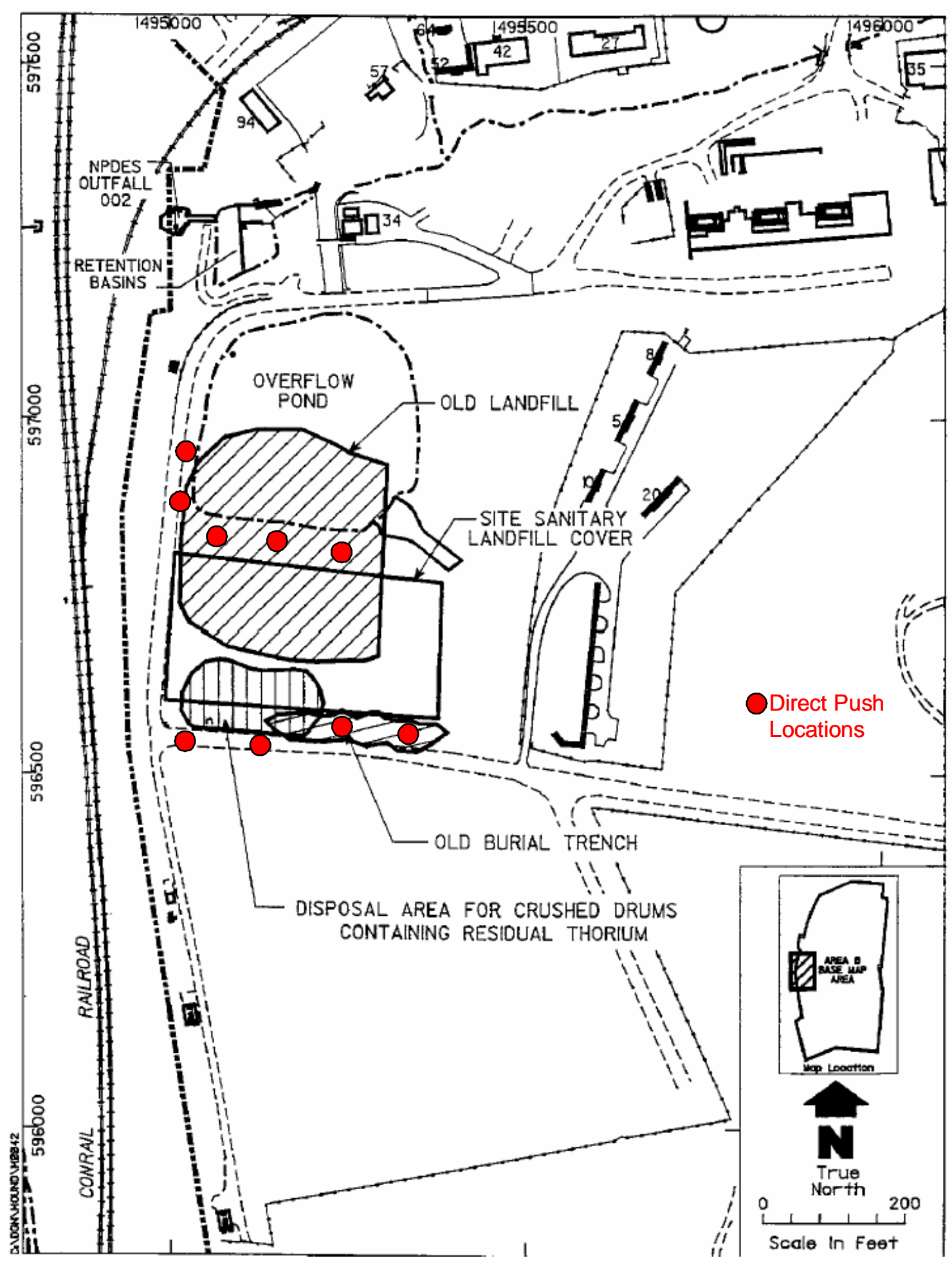

Figure 4.2. Preliminary Recommendations for Direct Push Locations 

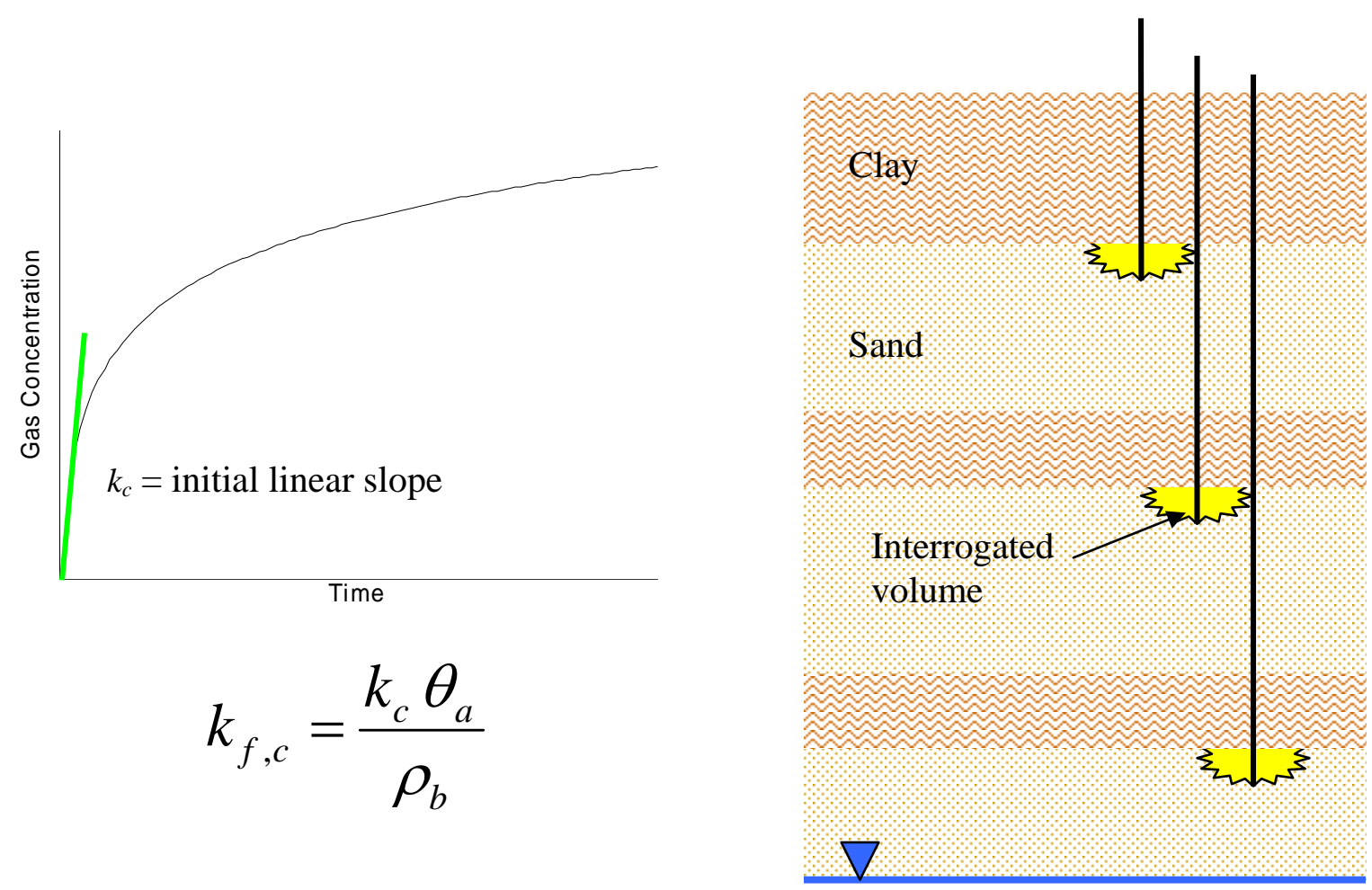

Figure 4-2. Graphical representation of the interrogated areas in the vadose zone and the concentration relationships after clean air injection. 


\subsection{Hydrology—Determination of Critical and Controlling Factors}

At the Mound Plant OU-1 plume, the flow direction has changed over time due to changes in the pumping regime as show below:

- 1950s to 1997: Groundwater flow is impacted by 3 plant production wells located to the south of OU-1. Typical system pumping rate: 700-800 gpm in 1950s and 1960s; $300-400 \mathrm{gpm}$ in 1990s. General groundwater flow direction in OU-1 is towards the south or southeast.

- 1997:2003: Groundwater flow is captured by 3 extraction wells at southern boundary of OU-1. Typical system pumping rate: $~ 100 \mathrm{gpm}$. General groundwater flow direction in OU-1 is towards the 3 extraction wells.

- 2003 to present: Groundwater extraction wells are shut down in May 2003 to initiate the rebound test. Extraction wells were turned back on in late February due to slight increase in VOC concentrations in selected monitoring wells. Plant production wells begin pumping at lower rates due to reduction in staffing at Mound Plant. General groundwater flow direction in OU-1 is towards the south or southeast.

- 2004: Plant production wells will be shut down as the facility begins to shift to supply from the city water system. General groundwater flow direction in OU-1 shift may towards the southwest (see Figure 4.3).

The change in groundwater flow direction has important implications for management of the chlorinated solvent plume at OU-1. The following potential characterization tasks could help determine how the groundwater flow direction may change in the future:

\subsubsection{Engineering Calculations}

Existing potentiometric surface maps of the BVA adjacent to the Mound Plant would be compiled and new maps would be constructed from water level elevation data. If possible, the maps would include data from the wells in and adjacent to OU-1 and include wells from areas farther away from extraction well and production well pumping. Maps would be compiled/developed for i) pre-extraction well pumping period; ii) period when the extraction wells were operating; iii) period with no extraction well pumping but with production wells pumping; iv) no extraction and no (or low) production well pumping. The potentiometric surface maps for the distant areas (areas not under the influence of the extraction/production wells) can be compared to maps from the areas near OU-1 (wells that are influenced by the extraction/production wells to estimate the future groundwater flow direction at OU-1. Groundwater velocity estimates would be developed using hydraulic conductivity data and the hydraulic gradient data derived from the potentiometric surface maps. 


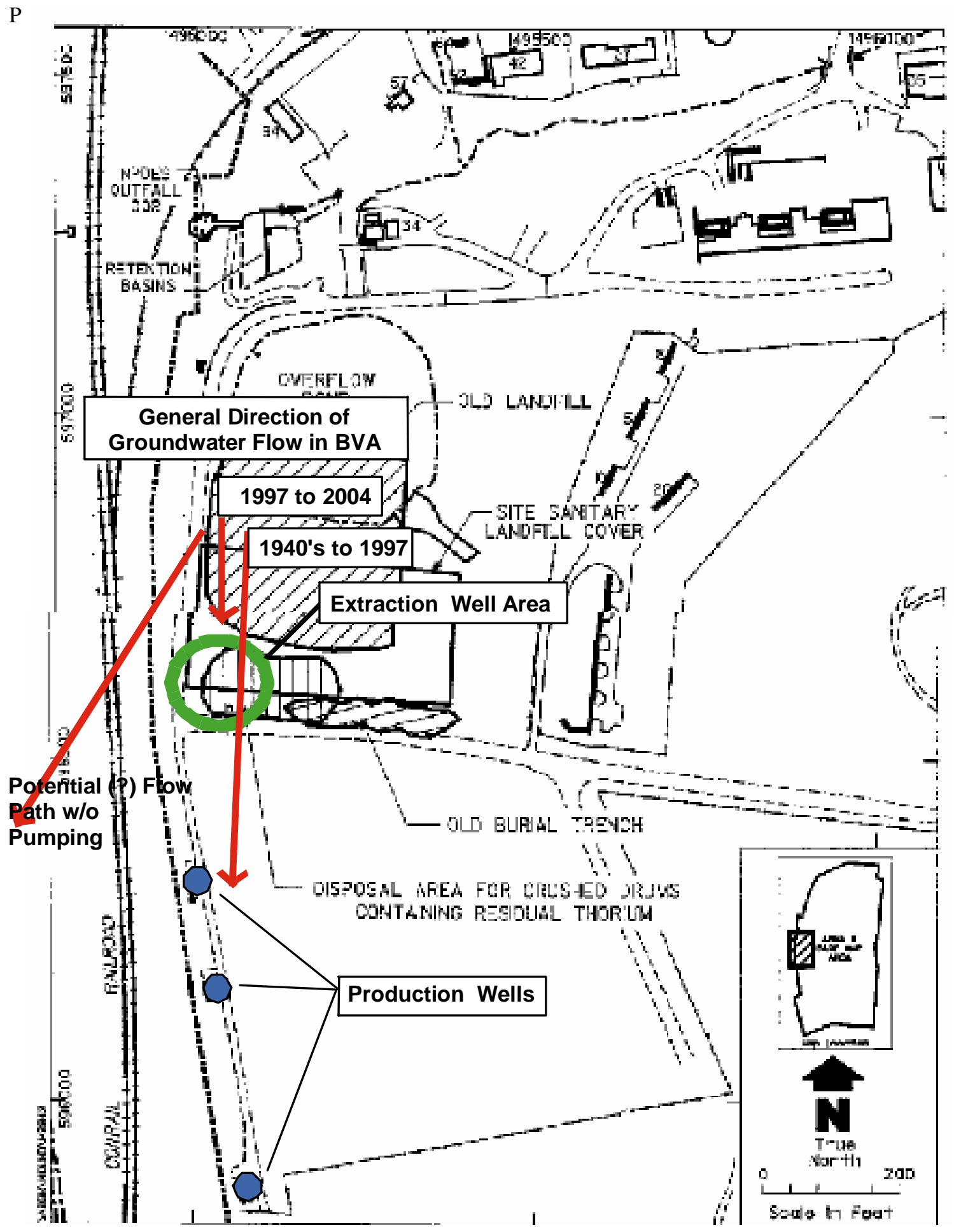

Figure 4-3. Change in Hydrologic Conditions and Groundwater Flow Direction Over Time. Groundwater Flow Directions are Approximate. 


\subsubsection{Apply Existing Groundwater Flow Model}

The existing MODFLOW model of the OU-1 buried valley aquifer system would be used to simulate the change (if any) in groundwater flow direction due to suspension of pumping of the extraction wells and plant production wells. If the groundwater flow direction under a no-pumping regime does not shift to the southwest then this alternative would not be needed. If this alternative is retained, the model would be used to determine which wells would need to be pumped and what pumping rate would be required. Groundwater velocity data can be developed using hydraulic conductivity data and the hydraulic gradient data derived from the potentiometric surface maps.

\subsubsection{Perform Tracer Tests}

A groundwater tracer test would be performed to provide information regarding the natural flow direction and groundwater flow velocity. One possible area for a tracer test would be at the midsection of OU-1 (see OU-1 Rebound Test Protocol). Bromide or another conservative tracer could be added to one well and then analyzed over time at downgradient and side-gradient wells. The resulting data would reflect site heterogeneities over the test domain. Some technical risk is involved due to the uncertainties in monitoring the tracer slug as it moves downgradient. 


\subsection{Attenuation Rates and Response to Amendments}

The U.S. EPA's Use of Monitored Natural Attenuation at Superfund, RCRA Corrective Action, and Underground Storage Tank Sites document (U.S. EPA, 1999) identifies three tiers of site-specific information or "lines of evidence" that can be used to evaluate the potential efficacy of monitored natural attenuation as a potential corrective measure. These lines of evidence are summarized as follows:

Historical groundwater data that demonstrate a clear and meaningful trend of decreasing contaminant mass and/or concentration over time at appropriate monitoring points. (First Line of Evidence)

Hydrogeologic and geochemical data that can be used to demonstrate indirectly the type(s) of natural attenuation processes at the site, and the rate at which such processes will reduce contaminant concentrations to required levels. (Second Line of Evidence)

Data from field or microcosm studies which directly demonstrate the occurrence of a particular natural attenuation process, and its ability to degrade contaminants of concern. (Third Line of Evidence)

\subsubsection{First Line of Evidence}

The analysis of the first line of evidence typically involves constructing concentration vs. time data at monitoring plumes within the plume. However, the operation of the OU-1 pump-and-treat system between 1997 and late 2003 has affected the concentration vs. time record and makes the analysis of trend data more difficult.

To more accurately evaluate natural attenuation processes, trend data from wells with a temporal record before 1997 need to be analyzed. A preliminary review of the data for TCE based on an "eyeball” trend evaluation shows these trends: 


\begin{tabular}{|c|c|c|c|c|c|}
\hline Well & $\begin{array}{c}\text { Well } \\
\text { Location* }\end{array}$ & Data Record & $\begin{array}{l}\text { Approximate } \\
\text { Concentration at } \\
\text { Beginning of } \\
\text { Record (ppb) }\end{array}$ & $\begin{array}{l}\text { Approximate } \\
\text { Concentration in } \\
1997 \text { (or End of } \\
\text { Record if before } \\
\text { 1997) (ppb) }\end{array}$ & Estimated Trend \\
\hline 0370 & Upgradient & $1993-2004$ & $50-160$ & $50-160$ & No Trend \\
\hline 0305 & $\begin{array}{l}\text { Downgradient } \\
\text { - Mid }\end{array}$ & $1990-2004$ & $20-60$ & $10-20$ & DECREASING \\
\hline 0374 & $\begin{array}{l}\text { Downgradient } \\
\text { - East }\end{array}$ & $1993-2004$ & $15-40$ & $15-40$ & No Trend \\
\hline 0410 & $\begin{array}{l}\text { Downgradient } \\
\text { - East }\end{array}$ & $1994-2004$ & $15-35$ & $25-30$ & No Trend \\
\hline 0373 & Interior & $1993-2004$ & $30-35$ & $30-35$ & Limited Data \\
\hline P015 & $\begin{array}{l}\text { Downgradient } \\
\text { - East }\end{array}$ & $1994-2004$ & $28-34$ & $30-50$ & INCREASING (?) \\
\hline 0402 & $\begin{array}{l}\text { Downgradient } \\
\text { - Distant }\end{array}$ & $1993-2004$ & $1-30$ & $1-5$ & DECREASING \\
\hline 0046 & Upgradient & $1986-1994$ & 14 & 4 & DECREASING \\
\hline 0313 & Upgradient & $1990-2004$ & $6-12$ & $2-5$ & DECREASING \\
\hline 0397 & Interior & $1993-2004$ & $6-12$ & $6-12$ & Limited Data \\
\hline 0307 & Upgradient & $1990-1995$ & $7-10$ & $4-8$ & DECREASING \\
\hline P027 & $\begin{array}{l}\text { Downgradient } \\
\text { - Distant }\end{array}$ & $1994-2004$ & $5-6$ & $4-5$ & No Trend \\
\hline PO31 & $\begin{array}{l}\text { Downgradient } \\
\text { - Distant }\end{array}$ & $1995-2004$ & $2.5-3$ & 3-3.5 & Limited Data \\
\hline 0379 & Upgradient & $1993-2004$ & $1-3$ & $1-3$ & Limited Data \\
\hline 0317 & $\begin{array}{l}\text { Downgradient } \\
\text { - Distant }\end{array}$ & $1990-2004$ & $<1.2$ & $<1.2$ & $\begin{array}{l}\text { STABLE; LESS } \\
\text { THAN DET. } \\
\text { LIMIT }\end{array}$ \\
\hline
\end{tabular}

- Locations based on classification used in OU-1 Rebound Test Technical Proposal. 
Overall these data shows a general decreasing trend in the OU-1 plume prior to pumping. In some wells (e.g., 0305, 0402, 0046) the decline in concentration was significant, i.e., by a factor of two or more in less than five years. The observed decreasing trends were due to natural attenuation processes, and indicate that in the absence of the pump-and-treat system there is the potential for applying monitored natural attenuation (MNA) as a corrective measure to treat the remaining low-concentration chlorinated solvent plume.

As a scoping exercise, the technical assistance team organized the VOC groundwater data for OU-1 into a spreadsheet to facilitate graphing TCE and PCE and the potential daughter products as a function of time. As noted above, most of the OU-1 monitoring wells showed a decreasing concentration trend. Figures 4-5 through 4-10 demonstrate the type of evaluation performed to support the First Line of Evidence. The figures depict concentration time trends for the downgradient mid-plume well 305. This well has a relatively long period of record and is generally representative of the OU-1 wells. Figure 4-5 shows the trends for all of the chlorinated ethenes. Figure 4-5 clearly shows that all of the chlorinated ethenes were decreasing over time, even before the initiation of SVE and P\&T. P\&T and SVE resulted in somewhat complex and interesting impacts on groundwater concentrations. The concentrations of cis-DCE and VC declined sharply during active remediation operations, while the concentrations of the PCE and TCE parents decreased slightly from the previous trends. The data suggest that the degradation and attenuation processes that were generating the daughter products were depressed during operation. The changes in PCE and TCE appear reasonable in terms of simple mass removal keeping up with the slow mass release from the vadose zone. The trends for PCE, TCE, DCE and VC are more clearly shown on Figures 4-6 through 4-9. The incremental benefit of operation is seen during the 1997 to 2003 period and the post operational rebound appears to be approaching the original time trend. Figure 4-10 shows the ratio of TCE to PCE during the different operational periods. This graph provides additional evidence that reductive degradation processes are depressed slightly by system operation. 


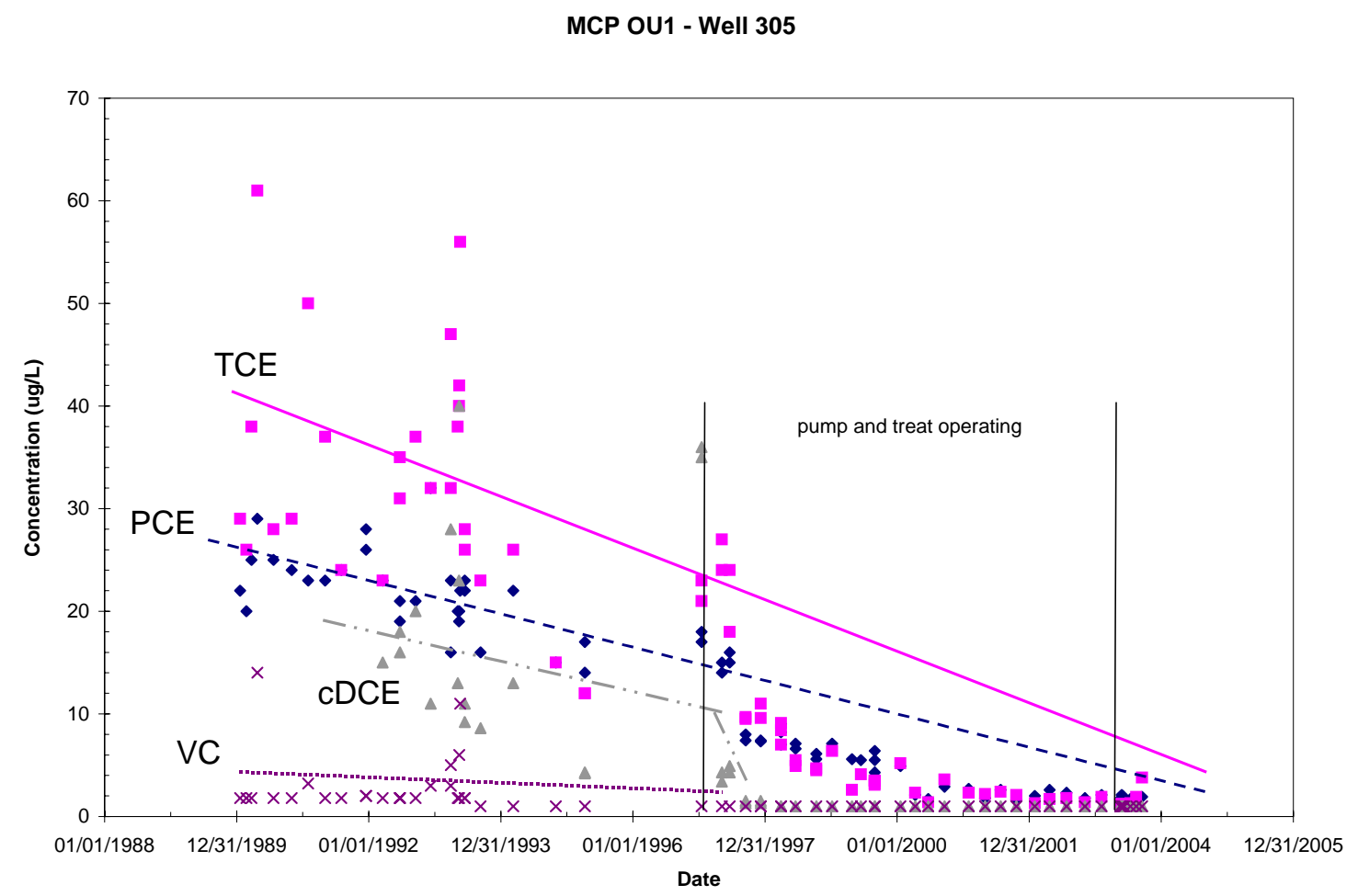

Figure 4-4. Chlorinated ethene time trends in MCP Well 305 


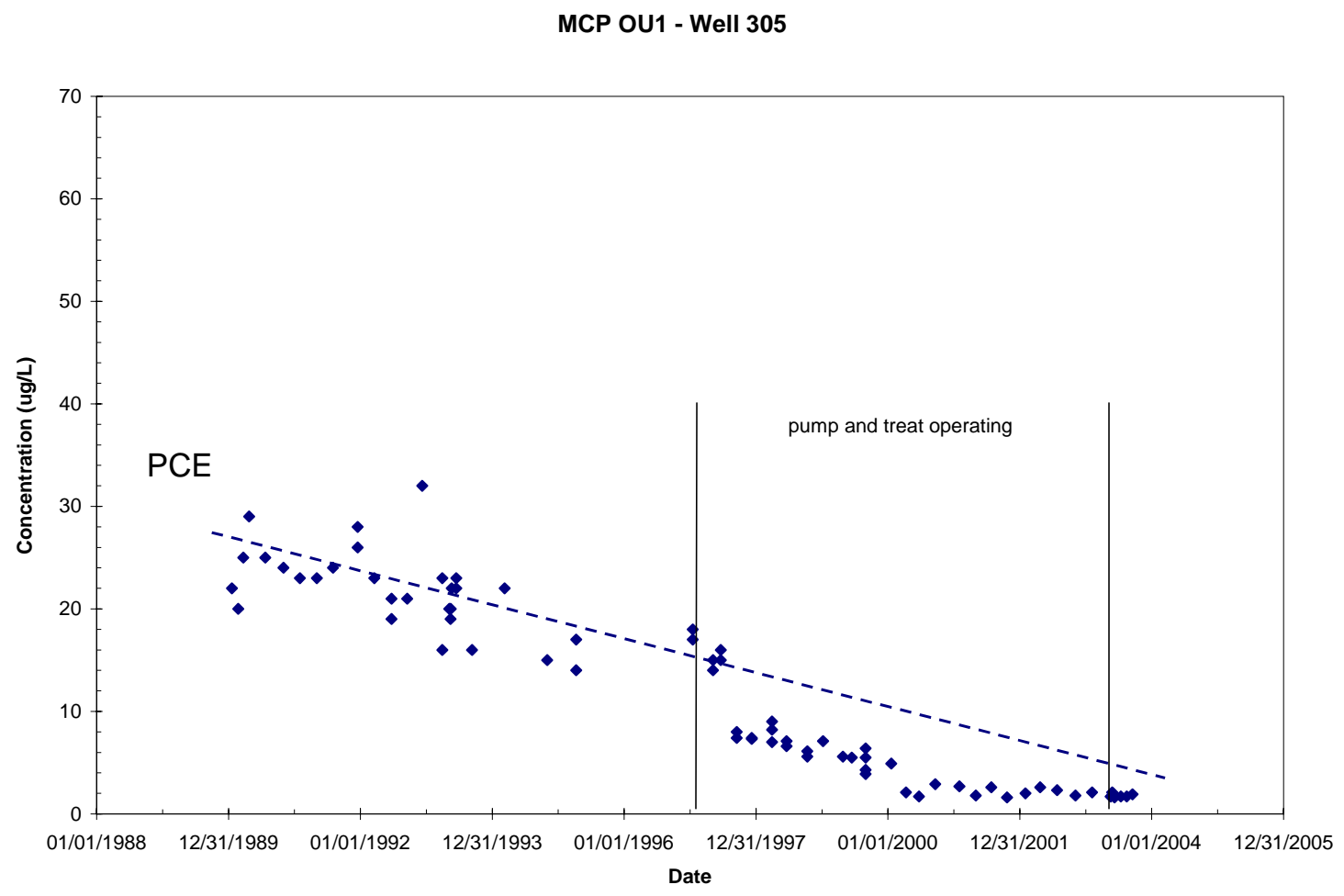

Figure 4-5. PCE time trends in MCP Well 305 


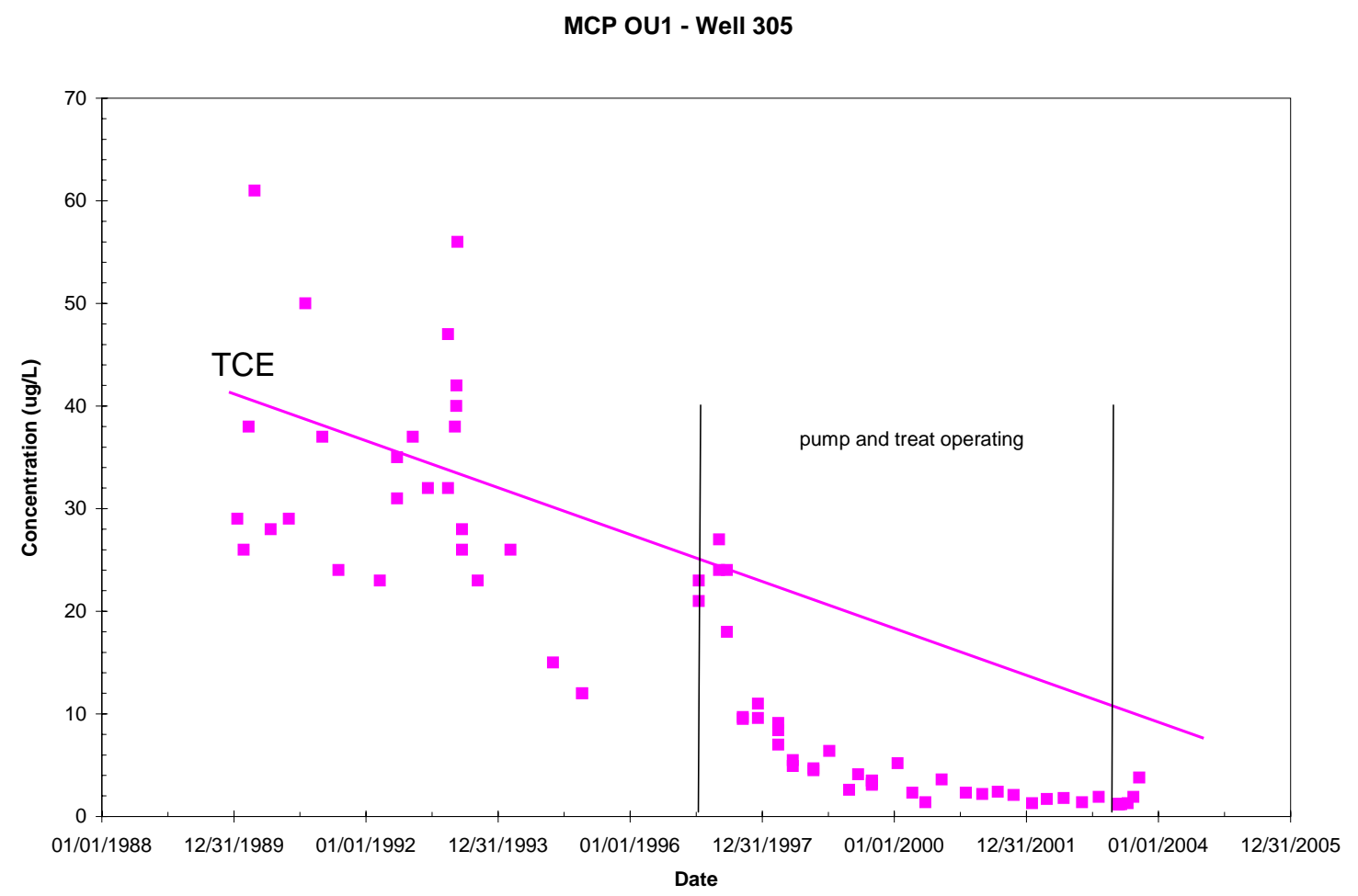

Figure 4-6. TCE time trends in MCP Well 305 
MCP OU1 - Well 305

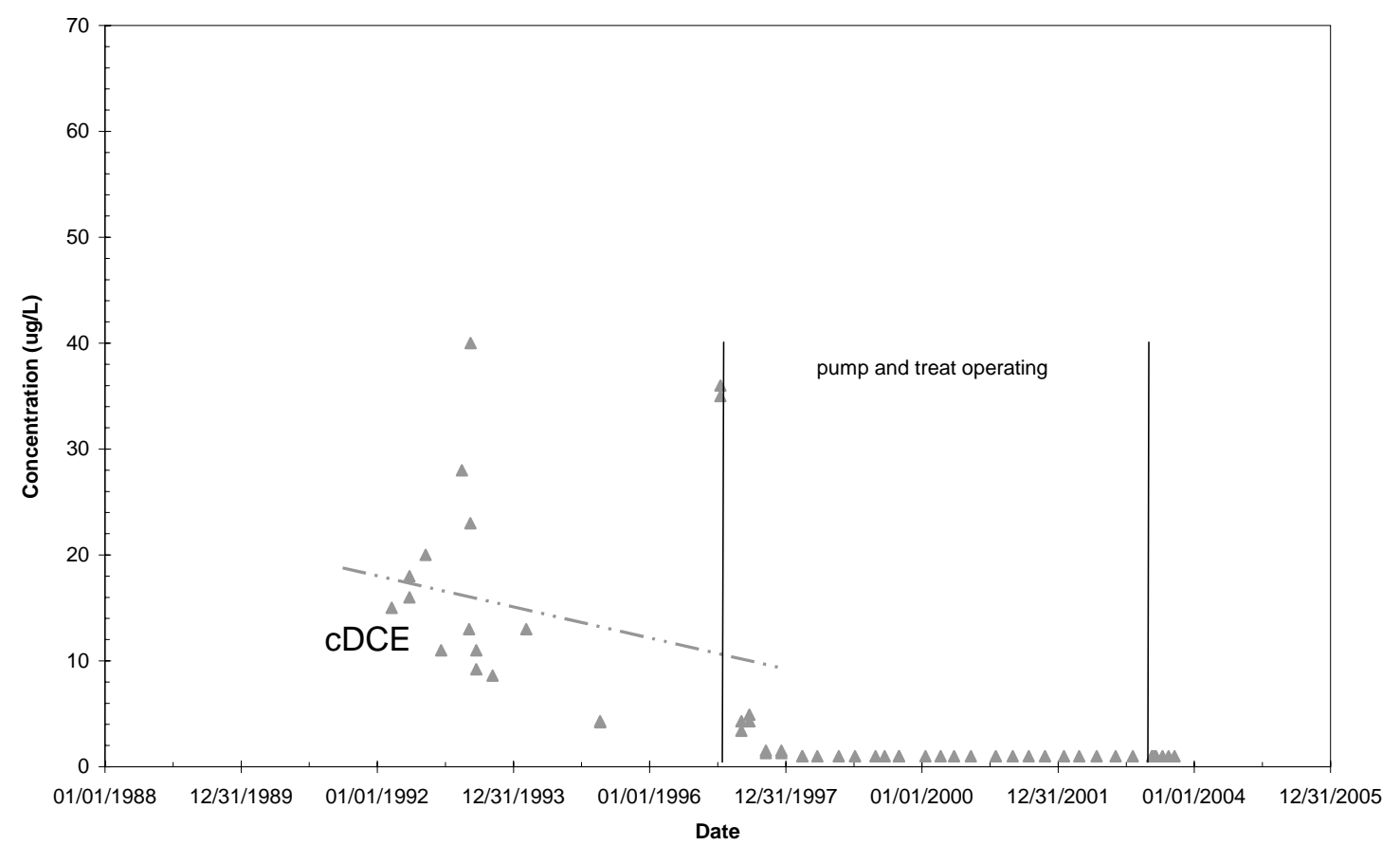

Figure 4-7. cis-DCE time trends in MCP Well 305 
MCP OU1 - Well 305

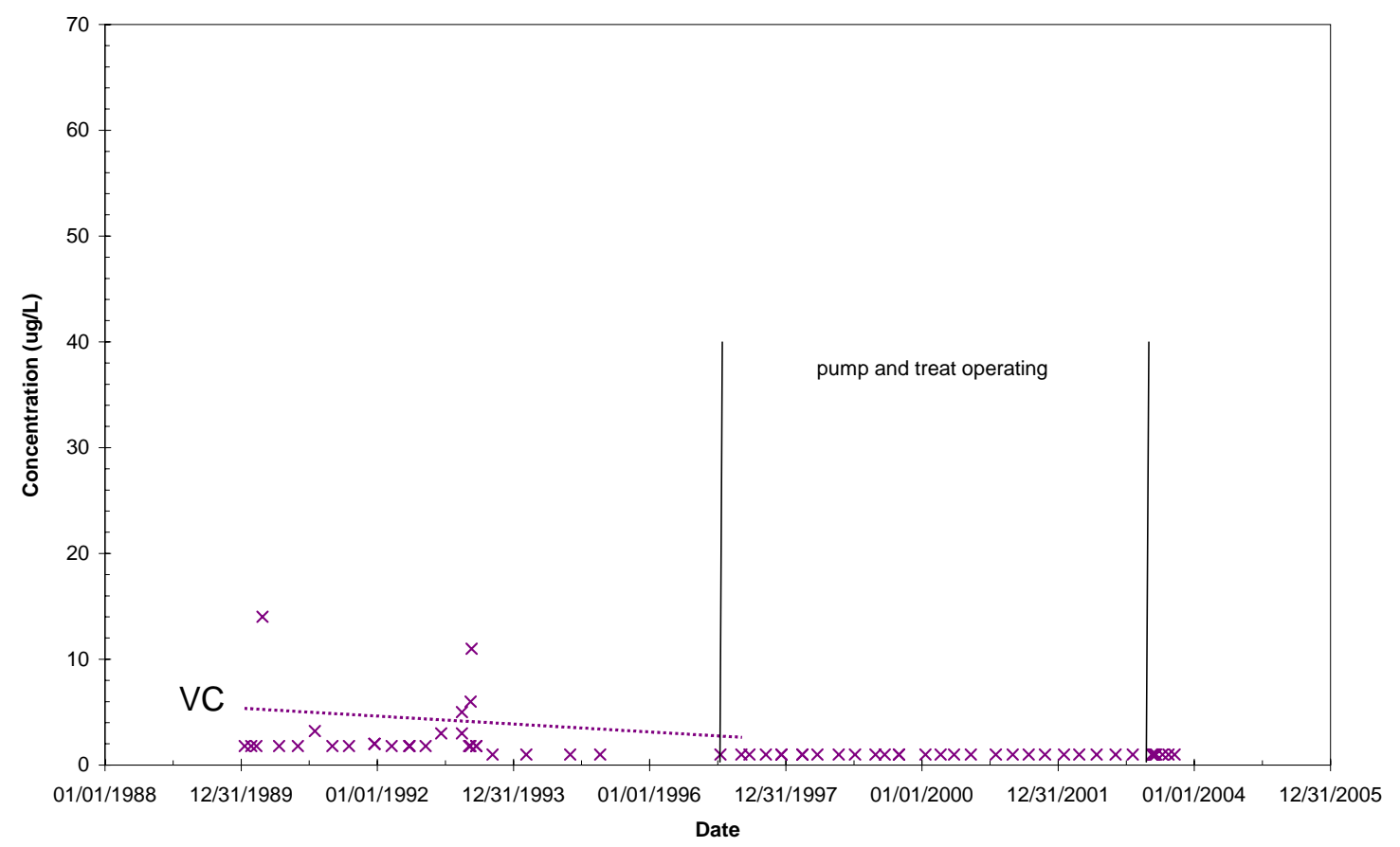

Figure 4-8. VC time trends in MCP Well 305 
MCP OU1 - Well 305

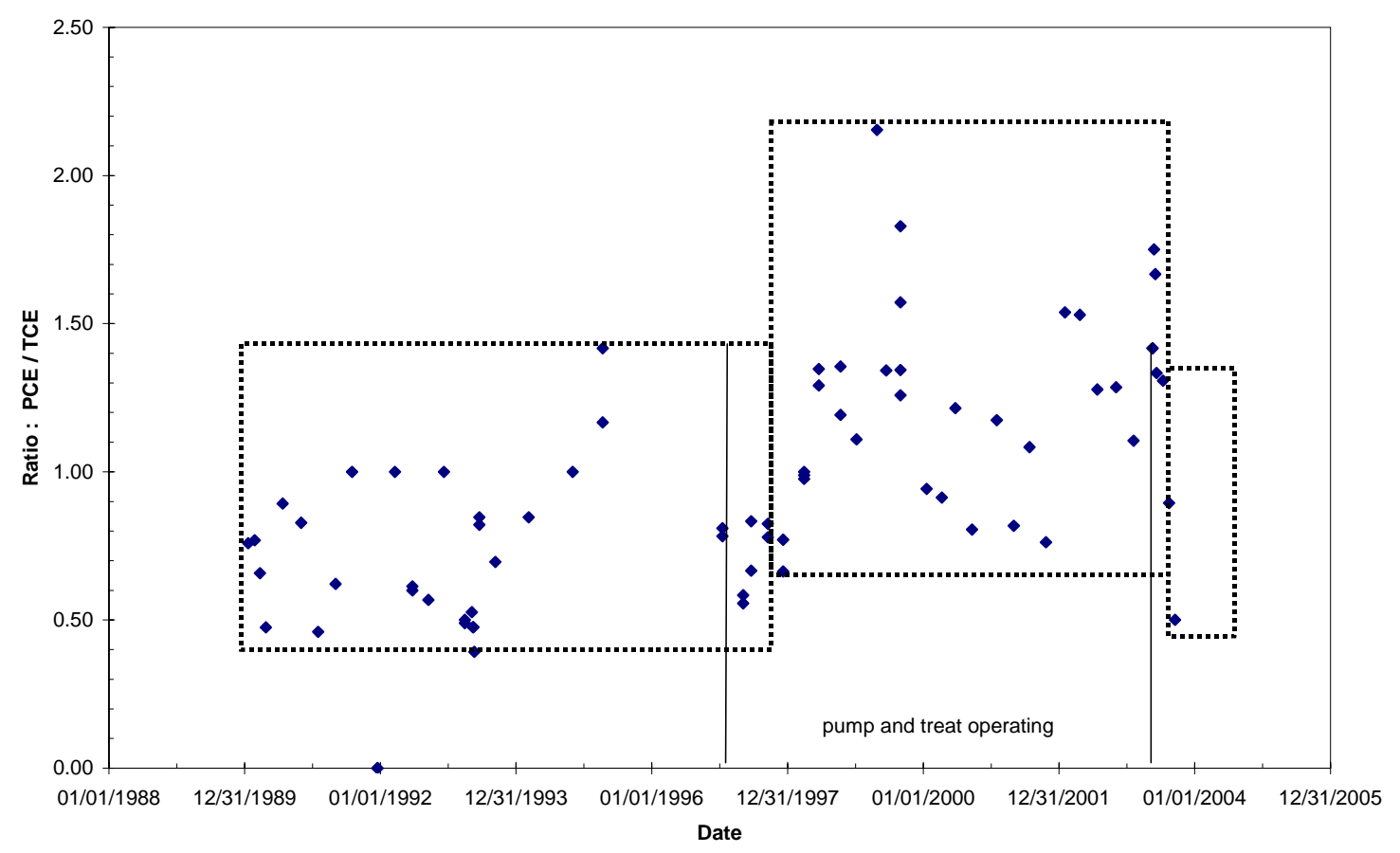

Figure 4-9. PCE TCE Ratio time trend in MCP Well 305 
More detailed work would involve the following tasks:

\subsubsection{Further Analysis of Concentration vs. Time Trends}

Chlorinated VOC data would be plotted against time for selected monitoring wells in various parts of the plume. To calculate point decay rates, the slope of natural log vs. time plots would be calculated (Newell et al., 2003). For wells with a negative slope, remediation timeframes would be estimated using the point decay rates. A more detailed assessment would involve using statistical analysis of concentration trends, such as the Mann Kendall analysis and associated methods (e.g., Aziz et. al, 2003). Overall plume stability (performed by lumping trend results from individual monitoring wells) could be assessed using tools such as the MAROS software system (Aziz et al., 2000).

\subsubsection{Second Line of Evidence}

The second line of evidence is performed to identify if geochemical conditions are appropriate for key natural attenuation reactions. In the case of MNA for chlorinated ethene solvent plumes, redox conditions and the terminal electron acceptor data are analyzed to determine if conditions support the biodegradation of PCE and TCE (and their daughter products) can be degraded by biological processes. This analysis is referred to as assessing for the presence of geochemical "footprints" of key natural attenuation biodegradation processes (Wiedemeier et al. 1999; NRC, 2000).

A preliminary analysis of the site groundwater data shows that:

- Geochemical footprints of anaerobic biodegradation (reductive dechlorination) are visible in the groundwater monitoring data prior to the startup of the pump-and-treat system in 1997 as evidence by redox and dissolved oxygen data.

- After the startup of the pump-and-treat system the footprints became less obvious, potentially because the parent compound sources were deleted and/or fresh groundwater converted previously anaerobic groundwater to more aerobic conditions that are less conducive to anaerobic biodegradation.

- Background (upgradient) sulfate concentrations are moderate to high (100-200 mg/L), which may reduce the efficiency of anaerobic biodegradation reactions but would not likely cause conditions such as "cis-DCE stall” where beneficial anaerobic biodegradation reactions are impaired.

More detailed work would involve additional site characterization work based on accepted MNA protocols (e.g., Wiedemeier et al., 1998) to evaluate geochemical footprints: 
Evaluate Geochemical Footprints for MNA. A subset of 10-15 wells would be monitored for electron donor and electron acceptors in the plume. Specifically, the following parameters would be monitored:

- Dissolved oxygen

- $\mathrm{pH}$

- Redox potential

- Temperature

- Specific conductance

- Nitrate

- Ferrous Iron

- Sulfate

- Methane/Ethane/Ethene

- Carbon dioxide

- Alkalinity

- Chloride

- Dissolved hydrogen (optional)

The wells would be selected to represent different portions of the plume, such as upgradient wells, wells in the overflow pond area, wells the landfill area, wells in the fringe of the plume, wells in the highest concentration zones, and downgradient wells. The data would be analyzed by constructing maps of key parameters and by constructing concentration vs. distance plots of nitrate, sulfate, iron, methane, ethane + ethane, and dissolved hydrogen.

\subsubsection{Evaluation of Subsurface Sulfate Sources}

Sulfate is an important electron acceptor in systems for which monitored natural attenuation is considered. This is because methanogenic conditions must be reached to support reductive dechlorination of TCE. As long as there is significant sulfate in the groundwater it will accept electrons and prevent methanogenesis. The source of the sulfate is also important. Sulfate that was disposed in waste solutions has a limited mass that can be depleted by anaerobic bacterial activity. In contrast, sulfate may originate from aquifer minerals or solid debris disposed in the area. Though these sources are finite, they provide a long-term continuous supply of sulfate to groundwater. If the rate of sulfate degradation is slower than the flux into the groundwater, then methanogenic conditions will not be achieved. Disposed debris such as plaster, sheetrock, and other construction materials can supply sulfate. Natural sources include gypsum $\left(\mathrm{CaSO}_{4} \cdot 2 \mathrm{H}_{2} \mathrm{O}\right)$, alunite $\left(\mathrm{KAl}_{3}\left(\mathrm{SO}_{4}\right)_{2}(\mathrm{OH})_{6}\right)$ and pyrite $\left(\mathrm{FeS}_{2}\right)$ in an aquifer. It is also possible that groundwater from bedrock that flows into the BVA may contain sufficient sulfate to provide a constant supply. Denham et al (2003) observed pyrite in samples of bedrock. Likewise they report elevated sulfate in the bedrock groundwater. Some of this may discharge into the BVA near OU-1providing a continuous source of sulfate to the BVA.

Additional geochemical calculations and review of the historical data could eliminate this issue as an uncertainty and a potential limitation to natural attenuation or biostimulation. Specifically, to determine the source and flux of sulfate into the BVA groundwater we 
recommend analyses of sulfate, calcium, potassium, and aluminum concentrations. With these measurements, it can be determined if the waters are saturated with gypsum or alunite. Groundwater from 3 BVA wells reported in Denham et al. (2003) are very close to saturation with alunite and somewhat under saturated with gypsum. The presence of either of these minerals would supply a continuous flux of sulfate to the aquifer. If these analyses suggest the presence of either of these minerals, then mineralogical analyses might be warranted to confirm this. These analyses are inexpensive and it is possible that existing data can be used.

Natural Attenuation Modeling. An analytical solute transport model (such as the BIOCHLOR model (Aziz et al., 1999) could be used to provide an integrated platform to analyze site data and indirectly show degradation processes are active at the site. For this application, the following data would be entered into the model:

- Hydrogeologic data (measured values for hydraulic conductivity, hydraulic gradient)

- Dispersivity data (estimated)

- Sorption data (estimated values for organic carbon on soil and literature values for partition coefficients)

- Biodegradation rates (calibrated against concentration vs. time data)

- Source data: (site maps and concentration data)

The results from the modeling analysis can be used to: i) evaluate if the plume is likely to be stable or will continue to expand, and ii) provide degradation rate of VOCs in groundwater. When run in a no degradation mode, the model can indicate if a "no action" scenario would result in unacceptable plume lengths.

\subsubsection{Third Line of Evidence}

The third line of evidence involves collecting data that directly supports the presence of naturally occurring degradation processes. At this site there is currently direct evidence that anaerobic biodegradation is occurring as daughter products (cis-DCE and vinyl chloride) have been observed in groundwater.

To fully develop this line of evidence, the following tasks could be performed:

Evaluate Presence of Degradation Products. Existing VOC data would be analyzed to demonstrate the presence of key degradation products: TCE (in areas where PCE is present); cis-DCE, and vinyl chloride. The data analysis would consist of calculating parent:daughter ratios and mapping the results.

\subsubsection{Stable Isotope Analyses}

Bacteria in the soil preferentially degrade light isotopes of carbon first due to their higher enzyme affinity. Thus parent compounds that have significantly heavier isotope ratios of their carbon atoms if they have been biodegraded. This fractionation will also be apparent in daughter compounds which when taken as a whole will have significantly lower isotopic ratios. This allows determination of the degree of biodegradation of compounds found in the 
environment even at very low concentrations. The isotope ratios of TCE and its biodegradation byproducts, cis-dichloroethene ( cis-DCE), vinyl chloride (VC), and ethene, in groundwater samples can be preconcentrated with a combination of purge-and-trap and cryogenic techniques in order to allow for reproducible isotopic measurements of the low concentrations of these compounds in the samples (down to $0.04 \mu \mathrm{M}$, or $5 \mathrm{ppb}$, of TCE). Studies at other DOE sites has shown that compound specific stable isotope monitoring of chlorinated solvents can differentiate between the effects of groundwater transport, dissolution of DNAPL at the source, and enhanced bioremediation (Song et al., 2002). Isotope data from all wells within the zone of biostimulation influence exhibited large kinetic isotope effects during the reduction of c-DCE to VC and VC to ethene. Despite these large effects, the carbon isotope ratio of ethene in all these wells reached the carbon isotope ratios of the initial dissolved TCE, confirming the complete conversion of dissolved TCE to ethene. Other recent studies have demonstrated that stable isotopic fractionation by aerobic cometabolic bacteria is greater then for anaerobic bacteria demonstrating the stable isotopic analyses of TCE and $\mathrm{CO}_{2}$ can differentiate the dominant pathway in the environment that is degrading TCE or PCE (Barth et al., 2002). While these techniques are new they provide direct evidence of the biodegradation of PCE and TCE that is occurring in situ and thus are excellent measures for validation bioremediation and natural attenuation. However, currently these techniques are fairly expensive ( $>\$ 300 /$ sample) and make wide spread use on a regular basis cost prohibitive. In addition, only a few laboratories are capable of doing these types of analyses. They are recommended only as a further line of evidence for Mound that biodegradation of PCE and TCE has occurred if other lines of evidence are equivocal. Ground water from only a few key wells in the OU-1 area should be sampled for this type of analyses to demonstrate that the PCE and TCE remaining has been biodegraded and that the origin of the cis-DCE and VC is biodegradation. These types of analyses could also be used to analyze PCE, TCE, and $\mathrm{CO}_{2}$ from soil gas samples, especially in the landfill, to demonstrate the degree of biodegradation that may have occurred in this environment.

\subsubsection{Enrichments and Enumeration of VOC-Degrading Bacteria}

Soil bacteria that can degrade VOCs are common in nearly all subsurface environments; however, it is often useful for the stakeholders and regulators to have proof that bacteria capable of degrading PCE and TCE are present in the sediment and ground water. This type of analyses generally only needs to be done once at any given site. However, the direct enumeration of VOC-degraders can be useful in time series analyses on wells in the plume, especially during biostimulation to suggest rates of biodegradation. These analyses can also be useful to demonstrate that the correct microorganisms have been successfully stimulated and later to determine if further stimulation is necessary as electron donors become depleted. Enrichment assays take water or sediment samples and inoculate them in minimal media containing PCE or TCE and the target electron donor. After several days to a month the densities have increased enough to analyze the cultures for degradation of PCE or TCE and determination of the types of daughter products produced. If even more direct biotreatability evidence for complete mineralization is desired the enrichments can be inoculated with ${ }^{14} \mathrm{C}$ labelled PCE and TCE and then analyzed for ${ }^{14} \mathrm{C}$-labelled $\mathrm{CO}_{2}$ at discreet time periods to determine the potential rates of mineralization. There are standard protocols for these types of treatability studies and they have been widely used for many years. Given that nearly all contaminated sites have shown the ability to degrade PCE and TCE the cost and time of these 
studies has not been justified in recent years. Most recently direct enumeration of bacteria using PCR nucleic acid probes has been widely used to demonstrate that specific bacteria are present that can degrade PCE and TCE by halorespiration or co-metabolic. Some investigators have suggested that some of these analyses are necessary to demonstrate the complete reductive dechlorination to ethene is possible by naturally occurring bacteria. Indeed, several companies do these types of analyses especially for halorespirers like Dehalicoccoides ethogenes (Löffler et al., 2000) and methane-oxidizing bacteria, methanotrophs (Sayler, et al., 1995; Bowman et al., 1993). Since these enumerations do not require any incubation, they can be done rapidly and are fairly inexpensive, relative to enrichments. Initial characterization of several wells in the OU-1 plume can demonstrate the presence of PCE/TCE degraders and the possibly the rates of degradation that may be possible. Should Mound decide to use biostimulation at OU-1 these assays would be useful to demonstrate the efficacy of biostimulation techniques.

\subsubsection{Push-Pull Tests}

A specific type of single well tracer test, the "push-pull" test provides a powerful approach to interrogate moderate volumes in an aquifer. By adjusting the injected solution, the test can be configured to address a variety of objectives ranging from DNAPL presence/quantity to bioremediation potential to MNA. A typical test is configured as shown in Figure 4-11.

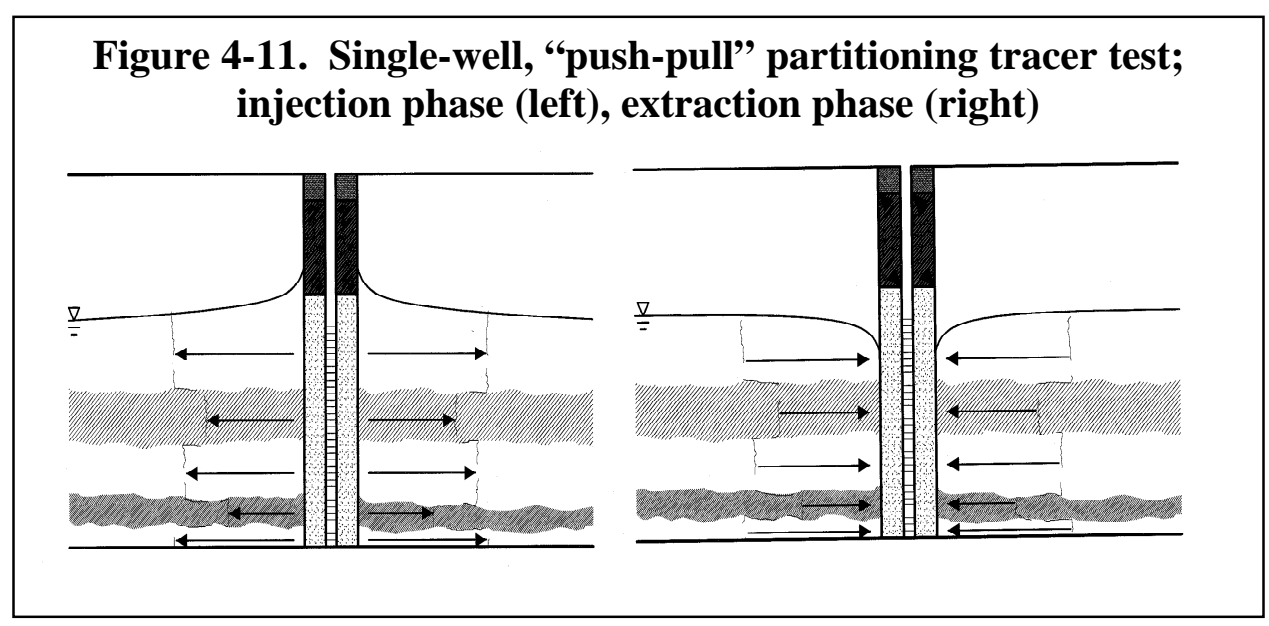

In this type of tracer test, water containing a non-partitioning tracer, a partitioning tracer, a contaminant surrogate, and/or a nutrient is injected into the saturated zone using an existing monitoring well; the injected test solution is then extracted from the same location. During the extraction phase, water samples are collected and analyzed for as needed to prepare breakthrough curves for the target solutes. Test breakthrough curves are analyzed using type-curves prepared by numerical modeling. Recently, Istok and others (1999) have applied this technique to the study of subsurface biological processes and to bioremediation design. While the method shows great promise, the team believes that the potential costs and resulting benefits for the MCP OU-1 site with its low concentration may not justify application at this time. 


\begin{tabular}{|c|c|c|c|c|c|c|c|c|c|}
\hline $\begin{array}{l}\text { Characteriza- } \\
\text { tion Technology } \\
\text { / Strategy }\end{array}$ & Objectives & Effectiveness* & $\begin{array}{l}\text { Regulatory } \\
\text { and Public } \\
\text { Acceptability }\end{array}$ & Implementability & Schedule & Cost** & $\begin{array}{l}\text { Long term } \\
\text { Perfomance }\end{array}$ & $\begin{array}{l}\text { Technical } \\
\text { Maturity }\end{array}$ & Overall \\
\hline $\begin{array}{l}\text { Soil gas } \\
\text { monitoring and } \\
\text { related methods }\end{array}$ & $\begin{array}{l}\text { Test } \\
\text { hypotheses } \\
\text { related to VOC } \\
\text { sources. } \\
\text { Particularly to } \\
\text { rule out other } \\
\text { major source } \\
\text { areas. Collect } \\
\text { data to validate } \\
\text { biodegradation } \\
\text { and attenuation } \\
\text { capacity. } \\
\text { Evaluate (or } \\
\text { eliminate) } \\
\text { potential for } \\
\text { source } \\
\text { structure } \\
\text { below water } \\
\text { table. }\end{array}$ & $\begin{array}{l}\text { Simple hypothesis } \\
\text { testing approach } \\
\text { using field } \\
\text { monitoring and } \\
\text { screening tools for } \\
\text { most analytes. } \\
\text { Some tools integrate } \\
\text { and interrogate } \\
\text { larger volumes. } \\
\text { Does not provide } \\
100 \% \text { certainty for } \\
\text { minor or widely } \\
\text { distributed sources. }\end{array}$ & $\begin{array}{l}\text { High. Uses } \\
\text { standard field } \\
\text { screening } \\
\text { methods and } \\
\text { tools. }\end{array}$ & Straightforward. & $\begin{array}{l}\text { Rapid } \\
\text { implementation } \\
\text { and data } \\
\text { interpretation } \\
\text { possible. }\end{array}$ & $\begin{array}{l}\text { Generally } \\
\text { Low (see } \\
\text { below) }\end{array}$ & Not applicable & $\begin{array}{l}\text { Mature and } \\
\text { available }\end{array}$ & $\begin{array}{l}\text { Viable and } \\
\text { recommended } \\
\text { by team as a } \\
\text { low cost } \\
\text { approach to } \\
\text { address a } \\
\text { variety of } \\
\text { objectives and } \\
\text { site needs. }\end{array}$ \\
\hline $\begin{array}{l}\text { Sampling gas } \\
\text { from the drain } \\
\text { pipe access into } \\
\text { cocoon }\end{array}$ & $\begin{array}{l}\text { Determine the } \\
\text { presence or } \\
\text { absence of } \\
\text { significant } \\
\text { VOC sources } \\
\text { in isolated } \\
\text { waste zone (or } \\
\text { in liner). } \\
\text { Provides data } \\
\text { on attenuation } \\
\text { mechanisms } \\
\text { and rates in } \\
\text { isolated waste. }\end{array}$ & $\begin{array}{l}\text { Analytes include } \\
\text { VOC and } \\
\text { breakdown } \\
\text { products, oxygen, } \\
\text { carbon dioxide, } \\
\text { methane. Based on } \\
\text { results, perform } \\
\text { respirometry and } \\
\text { VOC rebound tests. }\end{array}$ & $\begin{array}{l}\text { High. Uses } \\
\text { standard field } \\
\text { screening } \\
\text { methods and } \\
\text { tools. }\end{array}$ & Straightforward. & $\begin{array}{l}\text { Rapid } \\
\text { implementation } \\
\text { and data } \\
\text { interpretation } \\
\text { possible. }\end{array}$ & Low & $\begin{array}{l}\text { Not } \\
\text { applicable }\end{array}$ & $\begin{array}{l}\text { Mature and } \\
\text { available }\end{array}$ & $\begin{array}{l}\text { Viable and } \\
\text { recommended } \\
\text { by team. }\end{array}$ \\
\hline $\begin{array}{l}\text { Sampling gas } \\
\text { from the French } \\
\text { drains and other } \\
\text { soil gas access } \\
\text { outside of }\end{array}$ & $\begin{array}{l}\text { Determine the } \\
\text { if SVE has } \\
\text { reduced source } \\
\text { levels in soil } \\
\text { below and }\end{array}$ & $\begin{array}{l}\text { Analytes include } \\
\text { VOC and } \\
\text { breakdown } \\
\text { products, oxygen, } \\
\text { carbon dioxide, }\end{array}$ & $\begin{array}{l}\text { High. Uses } \\
\text { standard field } \\
\text { screening } \\
\text { methods and } \\
\text { tools. }\end{array}$ & Straightforward. & $\begin{array}{l}\text { Rapid } \\
\text { implementation } \\
\text { and data } \\
\text { interpretation } \\
\text { possible. }\end{array}$ & Low & $\begin{array}{l}\text { Not } \\
\text { applicable }\end{array}$ & $\begin{array}{l}\text { Mature and } \\
\text { available }\end{array}$ & $\begin{array}{l}\text { Viable and } \\
\text { recommended } \\
\text { by team. }\end{array}$ \\
\hline
\end{tabular}




\begin{tabular}{|c|c|c|c|c|c|c|c|c|c|}
\hline $\begin{array}{l}\text { Characteriza- } \\
\text { tion Technology } \\
\text { / Strategy } \\
\end{array}$ & Objectives & Effectiveness* & $\begin{array}{l}\text { Regulatory } \\
\text { and Public } \\
\text { Acceptability } \\
\end{array}$ & Implementability & Schedule & Cost** & $\begin{array}{l}\text { Long term } \\
\text { Perfomance }\end{array}$ & $\begin{array}{l}\text { Technical } \\
\text { Maturity }\end{array}$ & Overall \\
\hline cocoon & $\begin{array}{l}\text { surrounding } \\
\text { the cocoon. } \\
\text { Determine if } \\
\text { remaining } \\
\text { contaminants } \\
\text { are significant } \\
\text { source to } \\
\text { groundwater. } \\
\text { Provides data } \\
\text { on attenuation } \\
\text { mechanisms. }\end{array}$ & $\begin{array}{l}\text { methane. Based on } \\
\text { results, perform } \\
\text { respirometry and } \\
\text { VOC rebound tests. }\end{array}$ & & & & & & & \\
\hline $\begin{array}{l}\text { Geoprobe soil } \\
\text { gas sampling }\end{array}$ & $\begin{array}{l}\text { Similar to } \\
\text { above with } \\
\text { installation of } \\
\text { geoprobe } \\
\text { access to } \\
\text { extend soil and } \\
\text { OU1 } \\
\text { monitoring to } \\
\text { address other } \\
\text { potential } \\
\text { sources such } \\
\text { as the burn } \\
\text { cage to the } \\
\text { extent possible. }\end{array}$ & See above & See above & See above & See above & Low & See above & See above & See above \\
\hline $\begin{array}{l}\text { Extend geoprobe } \\
\text { through BVA } \\
\text { for water and } \\
\text { sediment } \\
\text { sampling }\end{array}$ & $\begin{array}{l}\text { Rule out } \\
\text { and/or identify } \\
\text { additional } \\
\text { sources to the } \\
\text { groundwater. } \\
\text { Depth } \\
\text { profiling } \\
\text { through the } \\
\text { BVA will } \\
\text { provide } \\
\text { specific } \\
\text { information to } \\
\text { assess or rule }\end{array}$ & $\begin{array}{l}\text { Analytes include } \\
\text { VOC and daughter } \\
\text { products, dissolved } \\
\text { oxygen,redox } \\
\text { potential, sulfate } \\
\text { and nitrate,and } \\
\text { organic carbon. If } \\
\text { necessary (e.g., low } \\
\text { permeability zones) } \\
\text { collect soil plugs } \\
\text { usingwireline coring } \\
\text { or similar tool. }\end{array}$ & $\begin{array}{l}\text { High. Uses } \\
\text { standard field } \\
\text { screening } \\
\text { methods and } \\
\text { tools. }\end{array}$ & Straightforward. & $\begin{array}{l}\text { Rapid } \\
\text { implementation } \\
\text { and data } \\
\text { interpretation } \\
\text { possible. }\end{array}$ & Low & $\begin{array}{l}\text { Not } \\
\text { applicable }\end{array}$ & $\begin{array}{l}\text { Mature and } \\
\text { available }\end{array}$ & $\begin{array}{l}\text { Viable and } \\
\text { recommended } \\
\text { by team as a } \\
\text { cost effective } \\
\text { adjunct if } \\
\text { geoprobe soil } \\
\text { gas studies are } \\
\text { being } \\
\text { performed. }\end{array}$ \\
\hline
\end{tabular}




\begin{tabular}{|c|c|c|c|c|c|c|c|c|c|}
\hline $\begin{array}{l}\text { Characteriza- } \\
\text { tion Technology } \\
\text { / Strategy }\end{array}$ & Objectives & Effectiveness* & $\begin{array}{l}\text { Regulatory } \\
\text { and Public } \\
\text { Acceptability }\end{array}$ & Implementability & Schedule & Cost** & $\begin{array}{l}\text { Long term } \\
\text { Perfomance }\end{array}$ & $\begin{array}{l}\text { Technical } \\
\text { Maturity }\end{array}$ & Overall \\
\hline & $\begin{array}{l}\text { out high } \\
\text { concentration } \\
\text { source lenses } \\
\text { within the } \\
\text { aquifer. If } \\
\text { zones of high } \\
\text { concentration } \\
\text { are observed, } \\
\text { tests to } \\
\text { determine the } \\
\text { significance of } \\
\text { these as a } \\
\text { source can be } \\
\text { performed. }\end{array}$ & & & & & & & & \\
\hline Hydraulic & $\begin{array}{l}\text { Examine flow } \\
\text { directions and } \\
\text { rates. } \\
\text { Specifically } \\
\text { evaluate the } \\
\text { potential } \\
\text { impacts of } \\
\text { turning off } \\
\text { production } \\
\text { wells. }\end{array}$ & $\begin{array}{l}\text { See specific } \\
\text { approach. }\end{array}$ & High & High & $\begin{array}{l}\text { See specific } \\
\text { approach below. }\end{array}$ & $\begin{array}{l}\text { See specific } \\
\text { approach } \\
\text { below. }\end{array}$ & Not applicable & $\begin{array}{l}\text { See specific } \\
\text { approach. }\end{array}$ & $\begin{array}{l}\text { See specific } \\
\text { approach } \\
\text { below. }\end{array}$ \\
\hline $\begin{array}{l}\text { Engineering } \\
\text { calculation }\end{array}$ & $\begin{array}{l}\text { Examine } \\
\text { objectives } \\
\text { using simple } \\
\text { calculations } \\
\text { such as } \\
\text { hydraulic } \\
\text { gradients, } \\
\text { potentiometric } \\
\text { surface maps } \\
\text { and darcy } \\
\text { velocity } \\
\text { calculations. }\end{array}$ & $\begin{array}{l}\text { Simple and } \\
\text { relatively effective } \\
\text { for general } \\
\text { information about } \\
\text { flow rates and } \\
\text { directions. }\end{array}$ & High & High & $\begin{array}{l}\text { Rapid } \\
\text { implementation } \\
\text { and data } \\
\text { interpretation } \\
\text { possible. }\end{array}$ & Low & $\begin{array}{l}\text { Not } \\
\text { applicable-- } \\
\text { but method } \\
\text { could be used } \\
\text { through time } \\
\text { as system } \\
\text { changes } \\
\text { following } \\
\text { pumping } \\
\text { modifications. }\end{array}$ & $\begin{array}{l}\text { High - } \\
\text { standard } \\
\text { and well } \\
\text { accepted } \\
\text { approach. }\end{array}$ & $\begin{array}{l}\text { Viable and } \\
\text { recommended }\end{array}$ \\
\hline modeling & Examine & Effective for general & High & High & Rapid & Low-uses & Not & High - & Viable and \\
\hline
\end{tabular}




\begin{tabular}{|c|c|c|c|c|c|c|c|c|c|}
\hline $\begin{array}{l}\text { Characteriza- } \\
\text { tion Technology } \\
\text { / Strategy } \\
\end{array}$ & Objectives & Effectiveness* & $\begin{array}{l}\text { Regulatory } \\
\text { and Public } \\
\text { Acceptability } \\
\end{array}$ & Implementability & Schedule & Cost** & $\begin{array}{l}\text { Long term } \\
\text { Perfomance }\end{array}$ & $\begin{array}{l}\text { Technical } \\
\text { Maturity }\end{array}$ & Overall \\
\hline & $\begin{array}{l}\text { objectives } \\
\text { existing } \\
\text { standard } \\
\text { numerical } \\
\text { model. }\end{array}$ & $\begin{array}{l}\text { information about } \\
\text { flow rates and } \\
\text { directions. Provide } \\
\text { more structure to } \\
\text { flow field than } \\
\text { above. }\end{array}$ & & & $\begin{array}{l}\text { implementation } \\
\text { and data } \\
\text { interpretation } \\
\text { possible. Use } \\
\text { existing } \\
\text { MODFLOW } \\
\text { model of BVA as } \\
\text { a base to build } \\
\text { upon. }\end{array}$ & $\begin{array}{l}\text { existing } \\
\text { model. }\end{array}$ & $\begin{array}{l}\text { applicable- } \\
\text { but method } \\
\text { could be used } \\
\text { through time } \\
\text { as system } \\
\text { changes } \\
\text { following } \\
\text { pumping } \\
\text { modifications. }\end{array}$ & $\begin{array}{l}\text { standard } \\
\text { and well } \\
\text { accepted } \\
\text { approach. }\end{array}$ & recommended \\
\hline Tracer testing & $\begin{array}{l}\text { Examine } \\
\text { objectives } \\
\text { using tracer } \\
\text { injection and } \\
\text { arrival time } \\
\text { measurements } \\
\text { at dowgradient } \\
\text { locations. }\end{array}$ & $\begin{array}{l}\text { Provide direct } \\
\text { evidence of flow } \\
\text { paths and time. } \\
\text { Provides data that } \\
\text { explicitly } \\
\text { incorporates field } \\
\text { heterogeneity. Only } \\
\text { provides data in a } \\
\text { limited portion of } \\
\text { the domain and may } \\
\text { require many wells } \\
\text { to be tested. Some } \\
\text { technical risk } \\
\text { (dilution and other } \\
\text { factors sometimes } \\
\text { limit interpretation). } \\
\text { Dependent on } \\
\text { ability to monitor } \\
\text { downgradient. }\end{array}$ & $\begin{array}{l}\text { Med to High- } \\
\text { may require } \\
\text { underground } \\
\text { injection } \\
\text { control permit. }\end{array}$ & $\begin{array}{l}\text { Med to High - } \\
\text { more complex than } \\
\text { alternatives. }\end{array}$ & $\begin{array}{l}\text { Medium -- more } \\
\text { lead time than } \\
\text { alternatives. } \\
\text { Requires more } \\
\text { data } \\
\text { interpretation }\end{array}$ & $\begin{array}{l}\text { Medium -- } \\
\text { more costly } \\
\text { than } \\
\text { alternatives. } \\
\text { Requires } \\
\text { frequent } \\
\text { sampling } \\
\text { and analysis } \\
\text { of multiple } \\
\text { wells for the } \\
\text { duration of } \\
\text { the test. }\end{array}$ & $\begin{array}{l}\text { Not } \\
\text { applicable- } \\
\text { but method } \\
\text { could be used } \\
\text { through time } \\
\text { as system } \\
\text { changes. } \\
\text { More difficult } \\
\text { to repeat than } \\
\text { alternatives.. }\end{array}$ & $\begin{array}{l}\text { High - } \\
\text { available. }\end{array}$ & $\begin{array}{l}\text { Viable but not } \\
\text { recommended } \\
\text { because } \\
\text { approach is } \\
\text { more complex } \\
\text { and requires } \\
\text { longer lead } \\
\text { time than } \\
\text { alternatives. } \\
\text { This is the } \\
\text { only method } \\
\text { that fully } \\
\text { accounts for } \\
\text { heterogeneity } \\
\text { and should be } \\
\text { considered } \\
\text { only if } \\
\text { necessary. }\end{array}$ \\
\hline $\begin{array}{l}\text { Natural } \\
\text { attenuation } \\
\text { capacity and } \\
\text { rates and data } \\
\text { to support } \\
\text { bioremediation }\end{array}$ & $\begin{array}{l}\text { Examine the } \\
\text { biodegradation } \\
\text { and other } \\
\text { attenuation } \\
\text { mechanisms } \\
\text { using a variety } \\
\text { of chemical } \\
\text { and biological } \\
\text { tests. }\end{array}$ & $\begin{array}{l}\text { See specific } \\
\text { approach. }\end{array}$ & $\begin{array}{l}\text { See specific } \\
\text { approach. }\end{array}$ & $\begin{array}{l}\text { See specific } \\
\text { approach. }\end{array}$ & $\begin{array}{l}\text { See specific } \\
\text { approach below. }\end{array}$ & $\begin{array}{l}\text { See specific } \\
\text { approach. }\end{array}$ & Not applicable & $\begin{array}{l}\text { See specific } \\
\text { approach. }\end{array}$ & $\begin{array}{l}\text { See specific } \\
\text { approach. }\end{array}$ \\
\hline
\end{tabular}




\begin{tabular}{|c|c|c|c|c|c|c|c|c|c|}
\hline $\begin{array}{l}\text { Characteriza- } \\
\text { tion Technology } \\
\text { / Strategy } \\
\end{array}$ & Objectives & Effectiveness* & $\begin{array}{l}\text { Regulatory } \\
\text { and Public } \\
\text { Acceptability }\end{array}$ & Implementability & Schedule & Cost** & $\begin{array}{l}\text { Long term } \\
\text { Perfomance }\end{array}$ & $\begin{array}{l}\text { Technical } \\
\text { Maturity }\end{array}$ & Overall \\
\hline $\begin{array}{l}\text { Measures of } \\
\text { electron } \\
\text { acceptors and } \\
\text { electron donors } \\
\text {-geochemical } \\
\text { footprints }\end{array}$ & $\begin{array}{l}\text { Detemine if } \\
\text { geochemical } \\
\text { conditions are } \\
\text { appropriate } \\
\text { for } \\
\text { degradation } \\
\text { processes. }\end{array}$ & $\begin{array}{l}\text { Analytes include } \\
\text { sulfate, nitrate, } \\
\text { dissolved oxygen, } \\
\text { redox potential, } \\
\text { organic carbon and } \\
\text { methane, ethane } \\
\text { ethane and possibly } \\
\text { hydrogen. Provides } \\
\text { indirect evidence of } \\
\text { presence of } \\
\text { degradation } \\
\text { processes. Standard } \\
\text { technique for } \\
\text { evaluating MNA } \\
\text { processes. Existing } \\
\text { (historical) data } \\
\text { may be usable to } \\
\text { preliminarily screen } \\
\text { site and establich } \\
\text { past conditions. } \\
\text { Additional analyses } \\
\text { could augment this } \\
\text { data to determine } \\
\text { present conditions. }\end{array}$ & $\begin{array}{l}\text { Moderate. } \\
\text { Indirect } \\
\text { measure and } \\
\text { only provide } \\
\text { an indication } \\
\text { that conditions } \\
\text { are generally } \\
\text { supportive. } \\
\text { Can be } \\
\text { relatively } \\
\text { difficult to } \\
\text { explain }\end{array}$ & High & Rapid & $\begin{array}{l}\text { Low to Med } \\
\text { - consider } \\
\text { eliminating } \\
\text { hydrogen } \\
\text { for wells } \\
\text { with } \\
\text { moderate to } \\
\text { high } \\
\text { dissolved } \\
\text { oxygen and } \\
\text { redox. }\end{array}$ & $\begin{array}{l}\text { Not } \\
\text { applicable but } \\
\text { can repeated } \\
\text { periodically. }\end{array}$ & $\begin{array}{l}\text { Moderate } \\
\text { to high - } \\
\text { this is a } \\
\text { central set } \\
\text { of data } \\
\text { used in the } \\
\text { EPA MNA } \\
\text { protocol } \\
\text { multiple } \\
\text { lines of } \\
\text { evidence }\end{array}$ & $\begin{array}{l}\text { Viable and } \\
\text { recommended } \\
\text { - utilize } \\
\text { historical data } \\
\text { and new data } \\
\text { to assess } \\
\text { current } \\
\text { conditions and } \\
\text { impacts of } \\
\text { SVE and P\&T } \\
\text { on attenuation } \\
\text { capacity and } \\
\text { rates. }\end{array}$ \\
\hline $\begin{array}{l}\text { Concentration } \\
\text { time plots }\end{array}$ & $\begin{array}{l}\text { Determine if } \\
\text { historical } \\
\text { trends indicate } \\
\text { degradation } \\
\text { processes and } \\
\text { project time } \\
\text { frames and } \\
\text { rates. }\end{array}$ & $\begin{array}{l}\text { Graphical and trend } \\
\text { analysis of the } \\
\text { concentration } \\
\text { changes in various } \\
\text { portions of the site } \\
\text { to provide } \\
\text { information on } \\
\text { plume stability. } \\
\text { More detailed } \\
\text { approaches use } \\
\text { statistical methods } \\
\text { such as Mann- } \\
\text { Kendall analysis. }\end{array}$ & $\begin{array}{l}\text { Moderate. } \\
\text { Indirect } \\
\text { measure and } \\
\text { only providse } \\
\text { an lumped } \\
\text { estimate that } \\
\text { does not } \\
\text { account for } \\
\text { temporal } \\
\text { changes in } \\
\text { driving forces } \\
\text { (flow rates, } \\
\text { geochemical } \\
\text { conditions and }\end{array}$ & Moderate to High & Rapid & Low & $\begin{array}{l}\text { Not } \\
\text { applicable but } \\
\text { can repeated } \\
\text { periodically. }\end{array}$ & $\begin{array}{l}\text { Moderate } \\
\text { to high - } \\
\text { this is a } \\
\text { central set } \\
\text { of data } \\
\text { used in the } \\
\text { EPA MNA } \\
\text { protocol } \\
\text { multiple } \\
\text { lines of } \\
\text { evidence }\end{array}$ & $\begin{array}{l}\text { Viable and } \\
\text { recommended } \\
\text { - beneficial } \\
\text { use of } \\
\text { historical data }\end{array}$ \\
\hline
\end{tabular}




\begin{tabular}{|c|c|c|c|c|c|c|c|c|c|}
\hline $\begin{array}{l}\text { Characteriza- } \\
\text { tion Technology } \\
\text { / Strategy }\end{array}$ & Objectives & Effectiveness* & $\begin{array}{l}\text { Regulatory } \\
\text { and Public } \\
\text { Acceptability }\end{array}$ & Implementability & Schedule & Cost** & $\begin{array}{l}\text { Long term } \\
\text { Perfomance }\end{array}$ & $\begin{array}{l}\text { Technical } \\
\text { Maturity }\end{array}$ & Overall \\
\hline & & & the like). & & & & & & \\
\hline $\begin{array}{l}\text { Daughter } \\
\text { products }\end{array}$ & $\begin{array}{l}\text { Determine if } \\
\text { daughter } \\
\text { products are } \\
\text { present and } \\
\text { indicative of } \\
\text { sufficient } \\
\text { attenuation } \\
\text { capacity. }\end{array}$ & $\begin{array}{l}\text { Analytes include } \\
\text { PCE, TCE, DCE, } \\
\text { VC. Provides direct } \\
\text { evidence of presence } \\
\text { of degradation } \\
\text { processes. Standard } \\
\text { technique for } \\
\text { evaluating MNA } \\
\text { processes. Existing } \\
\text { (historical) data } \\
\text { may be usable to } \\
\text { preliminarily screen } \\
\text { site and establish } \\
\text { past conditions. } \\
\text { Additional analyses } \\
\text { could augment this } \\
\text { data to determine } \\
\text { present conditions. }\end{array}$ & High & High & Rapid & $\begin{array}{l}\text { Low - Uses } \\
\text { sampling } \\
\text { that is being } \\
\text { done as part } \\
\text { of baseline }\end{array}$ & $\begin{array}{l}\text { Not } \\
\text { applicable but } \\
\text { can repeated } \\
\text { periodically. }\end{array}$ & $\begin{array}{l}\text { High - this } \\
\text { is a central } \\
\text { set of data } \\
\text { used in the } \\
\text { EPA MNA } \\
\text { protocol } \\
\text { multiple } \\
\text { lines of } \\
\text { evidence }\end{array}$ & $\begin{array}{l}\text { Viable and } \\
\text { recommended } \\
\text { - beneficial } \\
\text { use of } \\
\text { historical data } \\
\text { and new data. }\end{array}$ \\
\hline $\begin{array}{l}\text { Natural } \\
\text { Attenuation } \\
\text { Modeling }\end{array}$ & $\begin{array}{l}\text { Utilize } \\
\text { screening tools } \\
\text { such as } \\
\text { BioChlor and } \\
\text { other models } \\
\text { to asses the } \\
\text { concentration- } \\
\text { time-distance } \\
\text { plots for the } \\
\text { plume using } \\
\text { available data } \\
\text { A dilution or } \\
\text { dispersion } \\
\text { model alone } \\
\text { (with no } \\
\text { degradation) } \\
\text { would support } \\
\text { no further } \\
\text { action }\end{array}$ & $\begin{array}{l}\text { Provides an } \\
\text { integrated } \\
\text { conceptual } \\
\text { approach to predict } \\
\text { plume stability and } \\
\text { size. Can be used to } \\
\text { build up } \\
\text { biodegradation rate } \\
\text { information and to } \\
\text { assess potential } \\
\text { EPR options. } \\
\text { Quality of results is } \\
\text { dependent of the } \\
\text { availability of key } \\
\text { data (see related } \\
\text { data collection } \\
\text { categories). Simple } \\
\text { models only provide } \\
\text { estimates for }\end{array}$ & $\begin{array}{l}\text { Moderate to } \\
\text { High - } \\
\text { standard tool } \\
\text { used to } \\
\text { document } \\
\text { attenuation at } \\
\text { sites. }\end{array}$ & High & $\begin{array}{l}\text { Rapid-may need } \\
\text { to wait for } \\
\text { updated data } \\
\text { collection on key } \\
\text { parameters. }\end{array}$ & Low & $\begin{array}{l}\text { Not } \\
\text { applicable but } \\
\text { can repeated } \\
\text { periodically. }\end{array}$ & $\begin{array}{l}\text { High - } \\
\text { recommend } \\
\text { ed models } \\
\text { distributed } \\
\text { by EPA. } \\
\text { Not a } \\
\text { requiremen } \\
\text { tof EPA } \\
\text { protocol } \\
\text { but has } \\
\text { been used } \\
\text { at many } \\
\text { successful } \\
\text { MNA sites } \\
\text { in the past } \\
5 \text { years. }\end{array}$ & $\begin{array}{l}\text { Viable and } \\
\text { recommended } \\
\text { - beneficial } \\
\text { use of } \\
\text { historical data } \\
\text { and new data. }\end{array}$ \\
\hline
\end{tabular}




\begin{tabular}{|c|c|c|c|c|c|c|c|c|c|}
\hline $\begin{array}{l}\text { Characteriza- } \\
\text { tion Technology } \\
\text { / Strategy }\end{array}$ & Objectives & Effectiveness* & $\begin{array}{l}\text { Regulatory } \\
\text { and Public } \\
\text { Acceptability }\end{array}$ & Implementability & Schedule & Cost** & $\begin{array}{l}\text { Long term } \\
\text { Perfomance }\end{array}$ & $\begin{array}{l}\text { Technical } \\
\text { Maturity }\end{array}$ & Overall \\
\hline & decision. & $\begin{array}{l}\text { centerline and make } \\
\text { limited use of some } \\
\text { field data. }\end{array}$ & & & & & & & \\
\hline $\begin{array}{l}\text { Estimate } \\
\text { subsurface } \\
\text { sources of } \\
\text { sulfate to } \\
\text { aquifer }\end{array}$ & $\begin{array}{l}\text { Evaluate the } \\
\text { flux of sulfate } \\
\text { from nearby } \\
\text { bedrock, } \\
\text { minerals and } \\
\text { debris to } \\
\text { groundwater } \\
\text { and assess the } \\
\text { significance as } \\
\text { a competing } \\
\text { electron } \\
\text { acceptor. }\end{array}$ & $\begin{array}{l}\text { Requires } \\
\text { geocemical } \\
\text { evaluation of } \\
\text { possible sources and } \\
\text { estimation of } \\
\text { generation rates and } \\
\text { spatial distribution. } \\
\text { Compare the results } \\
\text { to measured sulfate } \\
\text { in the system over } \\
\text { time. }\end{array}$ & high & High & Rapid & $\begin{array}{l}\text { Low- } \\
\text { particularly } \\
\text { if using } \\
\text { existing data }\end{array}$ & $\begin{array}{l}\text { Not } \\
\text { applicable but } \\
\text { can repeated } \\
\text { periodically. }\end{array}$ & $\begin{array}{l}\text { Uses well } \\
\text { documente } \\
d \text { scientific } \\
\text { principles } \\
\text { but - } \\
\text { innovative } \\
\text { use to help } \\
\text { assure } \\
\text { success of } \\
\text { any natural } \\
\text { attenuation } \\
\text { concept. }\end{array}$ & $\begin{array}{l}\text { Viable and } \\
\text { recommended } \\
\text { - beneficial } \\
\text { use of } \\
\text { historical data } \\
\text { and new data. }\end{array}$ \\
\hline Isotope studies & $\begin{array}{l}\text { Examine the } \\
\text { stable carbon } \\
\text { isotope profile } \\
\text { in VOC parent } \\
\text { and daughter } \\
\text { products or } \\
\text { terminal } \\
\text { product (e.g., } \\
\text { methane } \\
\text { carbon } \\
\text { dioxide) to } \\
\text { show } \\
\text { biological } \\
\text { fractionation. }\end{array}$ & $\begin{array}{l}\text { Pattern of } \\
\text { fractionation is } \\
\text { related to } \\
\text { breakdown - } \\
\text { cometaboloic } \\
\text { fractionation and } \\
\text { anaerobic may be } \\
\text { distinguished in } \\
\text { some cases. A } \\
\text { specific challenge at } \\
\text { OU1 area is the low } \\
\text { concentration of } \\
\text { reduced daughter } \\
\text { products at the } \\
\text { present time } \\
\text { (minimum levels for } \\
\text { using this method } \\
\text { are about } 5 \text { ppb of } \\
\text { each analyte). }\end{array}$ & $\begin{array}{l}\text { Moderate- } \\
\text { relatively new } \\
\text { method and } \\
\text { interpretation } \\
\text { may not be } \\
\text { absolute. } \\
\text { Difficult to } \\
\text { explain. }\end{array}$ & $\begin{array}{l}\text { Moderate - would } \\
\text { require detailed } \\
\text { planning and } \\
\text { coordination with } \\
\text { state of the art } \\
\text { geochemistry and } \\
\text { stable isotope } \\
\text { laboratory. }\end{array}$ & Medium & $\begin{array}{l}\text { Moderate -- } \\
\text { Relatively } \\
\text { high for } \\
\text { each well, } \\
\text { but data } \\
\text { could be } \\
\text { needed for } \\
\text { only a few } \\
\text { wells. }\end{array}$ & $\begin{array}{l}\text { Not } \\
\text { applicable but } \\
\text { can repeated } \\
\text { periodically. }\end{array}$ & $\begin{array}{l}\text { Moderate } \\
\text { to low }\end{array}$ & $\begin{array}{l}\text { Viable- } \\
\text { recommended } \\
\text { only if related } \\
\text { measures in } \\
\text { the multiple } \\
\text { lines of } \\
\text { evidence are } \\
\text { insufficient }\end{array}$ \\
\hline Push-pull tests & $\begin{array}{l}\text { In situ } \\
\text { treatbility test } \\
\text { (eliminates } \\
\text { some lab }\end{array}$ & $\begin{array}{l}\text { Limited experience } \\
\text { and effectiveness for } \\
\text { chlorinated solvents. } \\
\text { Interpretation can }\end{array}$ & $\begin{array}{l}\text { Moderate to } \\
\text { low - complex } \\
\text { interpretation } \\
\text { - especially for }\end{array}$ & $\begin{array}{l}\text { Moderate to } \\
\text { difficult-may } \\
\text { require } \\
\text { underground }\end{array}$ & $\begin{array}{l}\text { Moderate- may } \\
\text { require long lead } \\
\text { time }\end{array}$ & $\begin{array}{l}\text { Moderate to } \\
\text { high }\end{array}$ & $\begin{array}{l}\text { Not } \\
\text { applicable -- } \\
\text { can repeated } \\
\text { periodically. }\end{array}$ & $\begin{array}{l}\text { Moderate } \\
\text { to low }\end{array}$ & $\begin{array}{l}\text { May be viable } \\
\text { but not } \\
\text { recommended }\end{array}$ \\
\hline
\end{tabular}




\begin{tabular}{|c|c|c|c|c|c|c|c|c|c|}
\hline $\begin{array}{l}\text { Characteriza- } \\
\text { tion Technology } \\
\text { / Strategy } \\
\end{array}$ & Objectives & Effectiveness* & $\begin{array}{l}\text { Regulatory } \\
\text { and Public } \\
\text { Acceptability }\end{array}$ & Implementability & Schedule & Cost** & $\begin{array}{l}\text { Long term } \\
\text { Perfomance }\end{array}$ & $\begin{array}{l}\text { Technical } \\
\text { Maturity }\end{array}$ & Overall \\
\hline & $\begin{array}{l}\text { artifacts and } \\
\text { uncertainties) } \\
\text { Interrogate a } \\
\text { volume of } \\
\text { subsurface for } \\
\text { hydrologic and } \\
\text { chemical } \\
\text { parameters. If } \\
\text { done in } \\
\text { sequence with } \\
\text { injection of } \\
\text { electron } \\
\text { donors, these } \\
\text { can be used as } \\
\text { a design basis } \\
\text { for active } \\
\text { bioremediation } \\
\text { systems For } \\
\text { chlorinated } \\
\text { solvents, more } \\
\text { complex test } \\
\text { protocols are } \\
\text { needed then } \\
\text { for } \\
\text { hydrocarbons.. }\end{array}$ & $\begin{array}{l}\text { be complex and test } \\
\text { mey need to be } \\
\text { repeated in the same } \\
\text { well to allow } \\
\text { community to } \\
\text { equilibrate. Works } \\
\text { best at moderate } \\
\text { permeability. OU1 } \\
\text { area may be too } \\
\text { permeable because } \\
\text { injected water will } \\
\text { be lost rapidly prior } \\
\text { to extraction. }\end{array}$ & $\begin{array}{l}\text { chlorinated } \\
\text { solvents. } \\
\text { Difficult to } \\
\text { explain }\end{array}$ & $\begin{array}{l}\text { injection control } \\
\text { permit and } \\
\text { potentially } \\
\text { reinjection of } \\
\text { VOCs }\end{array}$ & & & & & \\
\hline Microcosm & $\begin{array}{l}\text { Treatability } \\
\text { tests } \\
\text { performed in } \\
\text { laboratory } \\
\text { with sediment } \\
\text { and/or water } \\
\text { from the site. } \\
\text { Provide data } \\
\text { that suggest } \\
\text { the presence of } \\
\text { degradation } \\
\text { mechanisms. }\end{array}$ & $\begin{array}{l}\text { Moderate - results } \\
\text { can be equivocal } \\
\text { and rates not } \\
\text { necessarily } \\
\text { representative of } \\
\text { field conditions. }\end{array}$ & $\begin{array}{l}\text { Moderate to } \\
\text { High }\end{array}$ & High & $\begin{array}{l}\text { Rapid to } \\
\text { moderate - } \\
\text { incubation times } \\
\text { can be } 30 \text { days or } \\
\text { more. }\end{array}$ & $\begin{array}{l}\text { Moderate to } \\
\text { High }\end{array}$ & $\begin{array}{l}\text { Not } \\
\text { applicable -- } \\
\text { can repeated } \\
\text { periodically. }\end{array}$ & High & $\begin{array}{l}\text { Viable- } \\
\text { recommended } \\
\text { only if related } \\
\text { measures in } \\
\text { the multiple } \\
\text { lines of } \\
\text { evidence are } \\
\text { insufficient }\end{array}$ \\
\hline VOC degrader & Utilize various & Provides direct & Regulators and & High & Rapid & Low to & $\mathrm{Not}$ & High & Viable-but \\
\hline
\end{tabular}




\begin{tabular}{|c|c|c|c|c|c|c|c|c|c|}
\hline $\begin{array}{l}\text { Characteriza- } \\
\text { tion Technology } \\
\text { / Strategy }\end{array}$ & Objectives & Effectiveness* & $\begin{array}{l}\text { Regulatory } \\
\text { and Public } \\
\text { Acceptability }\end{array}$ & Implementability & Schedule & Cost** & $\begin{array}{l}\text { Long term } \\
\text { Perfomance }\end{array}$ & $\begin{array}{l}\text { Technical } \\
\text { Maturity }\end{array}$ & Overall \\
\hline enumeration & $\begin{array}{l}\text { microbial } \\
\text { assessment } \\
\text { tools } \\
\text { (enrichments, } \\
\text { nucleic acid } \\
\text { probes, etc) to } \\
\text { show the } \\
\text { presence of } \\
\text { specific VOC } \\
\text { degrading } \\
\text { organisms. }\end{array}$ & $\begin{array}{l}\text { evidence of the } \\
\text { presence of } \\
\text { organisms. May not } \\
\text { indicate gene } \\
\text { expression or field } \\
\text { degradation rates. }\end{array}$ & $\begin{array}{l}\text { public like to } \\
\text { see that } \\
\text { appropriate } \\
\text { microorganism } \\
\text { s are present. } \\
\text { Limited value } \\
\text { for technical } \\
\text { design and } \\
\text { interpretation. }\end{array}$ & & & Moderate & $\begin{array}{l}\text { applicable -- } \\
\text { can repeated } \\
\text { periodically. }\end{array}$ & & $\begin{array}{l}\text { not required } \\
\text { and only need } \\
\text { one time -- } \\
\text { recommended } \\
\text { only for key } \\
\text { wells in } \\
\text { critical areas } \\
\text { beneath and } \\
\text { dowgradient } \\
\text { of residual } \\
\text { "sources." }\end{array}$ \\
\hline
\end{tabular}




\subsection{SITE MANAGEMENT, REMEDIATION AND CONFIGURATION}

Environmental remediation technologies can be viewed on a continuum ranging from highly invasive source excavation on one end to noninvasive MNA on the other end (Figure 1). This continuum represents technologies and strategies used during the period of remediation. Over time these approaches reduce and attenuate risks to meet the remediation goals. This results in a final status where the site requires no further action. As drawn, aggressive technologies such as direct in situ chemical destruction and thermal methods fall near the left of the continuum. Baseline pump and treat, active bioremediation and similar methods are near the center of the continuum. Permeable treatment systems fall to the right. A key aspect of the process of environmental management and decision-making is matching the technology to the site. Aggressive actions that are not justified tend to waste energy and resources and result in adverse collateral environmental damage, while not providing substantive risk reduction or benefit. Conversely, overly passive strategies do not provide the necessary progress toward remedial goals.

Importantly, the area adjacent to MNA on the continuum is designated EPR. This includes technologies that can be implemented and performance sustained in a manner analogous to MNA (e.g., permanently modifying hydrology or the special case of bioaugmentation with a missing microorganism). The two requirements for MNA/EPR, as described in the first paragraph, are the key to defining the allowable boundary of EPR. For sites where contaminant delivery from the source is less than the naturally sustainable attenuation capacity, MNA/EPR is viable. For sites where the contaminant delivery is greater than the attenuation capacity, but the attenuation processes or contaminant loading can be sustainably modified to achieve the required balance, then EPR is viable. Conversely, for sites where contaminant delivery from the source is greater than the sustainable attenuation capacity, then active remediation will be necessary. This continuum eliminates the historical dichotomy that has been strictly drawn between active remediation and natural attenuation. When combined with attenuation capacity paradigm, the continuum provides a quantitative basis for determining when MNA and EPR are useful and appropriate and what activities
Monitored Natural Attenuation (MNA) and Enhanced Passive Remediation (EPR) are straightforward strategies that are based on the natural and sustainable processes that degrade and attenuate contaminants at every site. To put this concept into beneficial use, there are two requirements. First, the principal degradation and attenuation processes at the site must be verified and their attenuation capacity estimated. Second, the resulting information needs to be evaluated to determine if the attenuation capacity within an acceptable distance is "enough" to attain site-specific environmental and regulatory objectives. This conceptual approach advocates working throughout the plume to quantify attenuation capacity. If the capacity of the system is not enough to address the contaminant plume, then the incremental increase in capacity that would be required to adequately address the plume can be determined. Such a combined calculation approach provides a powerful conceptual basis for improved environmental management and decision-making. (DOE, 2003) 
logically fit into the classifications. Importantly, a majority of contaminated sites will require a sequence of activities for responsible cleanup - often including source removal/destruction combined with treatment of a primary contaminant plume (the soil and groundwater that contain moderate to high concentrations). Virtually all sites will have a monitored natural attenuation component, either in the more dilute portion of the plume or after transitioning from more active treatment actions. The capacity based definitions and continuum will support a technical determination of how and when to transition from active remediation to MNA/EPR.

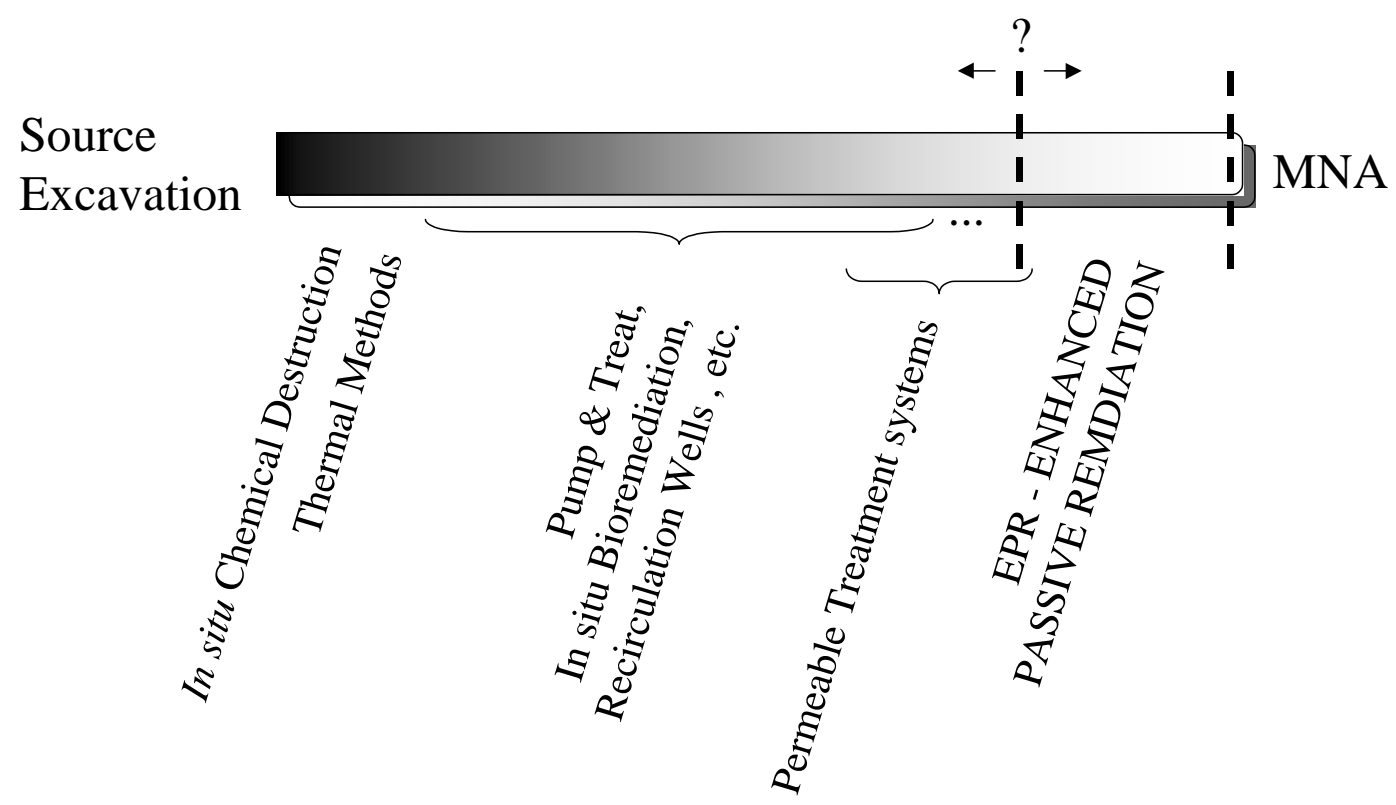

THE MCP OU-1 solvent plume has low concentrations. Thus, aggressive technologies (particularly chemical oxidation and thermal treatments) are not well matched to the site. At most sites, a sequence of technologies (or "technology train") is the optimal approach. The combinations are constructed by matching the strengths of the various methods to the specific needs of the site as a function of time. Similar to the characterization evaluation above, the results are discussed in the text and documented in a technology matrix. Based on the conditions at this site, the following technologies were evaluated by the team.

"No Further Action"

Continued operation of SVE

Continue Operation of groundwater P\&T

Monitored Natural Attenuation

Biostimulation (amendment based strategies including lactate, molasses, oil etc.)

Partitioning Barrier

Hydraulic Modification

Excavation

Combinations 


\section{1 “No Further Action”}

No further action may be an acceptable technical alternative if the determination can be made that existing concentrations pose little or no risk. Under the no further action scenario, an analysis would be performed that the VOCs in groundwater pose no further risk, and that the confidence in this assumption is high enough that no further monitoring is required to verify this conclusion. A key aspect of establishing such confidence would be explicit predictions of expected spatial and temporal plume behaviors and verification that the predictions are accurately reflected in monitoring data until agreed end state goals are achieved.

Technical factors that would be in favor of this alternative are:

- Concentrations are now very low, even with the rebound observed in some of the monitoring wells. For example, maximum TCE concentrations at OU-1 are now typically below 20 to $30 \mathrm{ppb}$, much lower than most chlorinated solvent plumes.

- No known receptors to the plume. The plant production wells are scheduled to be shut down in 2004, and groundwater extraction in areas to the west of the plant is prohibited by city ordinance. Therefore any plume migration would not pose a risk via groundwater ingestion.

- Some natural attenuation is likely to be occurring in the plume. A preliminary analysis of MNA processes at the OU-1 plume (see MNA section) indicates that MNA processes are likely to be present in the groundwater, further reducing the risk associated with the no action alternative.

Technical factors that could limit the acceptability of this technology are:

- The plume has the potential to migrate off-site to the southwest, particular after the plant production wells are shut off.

- There is uncertainty in how effective MNA processes are at controlling the migration of the plume.

- Compared to other alternatives, there may be higher initial costs as a result of the need to perform the additional characterization, modeling, and verification sampling studies. These studies are required to achieve the high degree of confidence necessary to support a no further action decision.

Non-technical factors will likely play a significant role in the evaluation of the no further action alternative. Note that no further action is the final stage of all remediation strategies and that all combinations of actions can be viewed as a sequence that leads to this end state. 


\subsection{Continued operation of SVE (Vadose zone source)}

Operation of the SVE system provided effective removal of VOCs from vadose zone in the OU-1 area. Concentrations decreased during operation and mass extraction rates at the end of operations were approximately $0.22 \mathrm{Kg} /$ day $(0.48 \mathrm{lb} /$ day $)$. While the system has operated and removed much of the easily accessible VOC, continued operation is viable and may be appropriate based on additional interpretation of the past concentration time trends and rebound data. Removal of VOC from vadose zone is significantly easier and less expensive than removal once leached into groundwater. As discussed below in the section on MNA, startup and operation of the SVE and P\&T systems appear to depress reductive dechlorination processes. This is likely the result of increasing the amount of oxygen and other competing electron acceptors entering the soil and groundwater plume area. Notably, the original system also included provision for air sparging below the water table. The team discourages use of air sparging at OU-1 because the technology is not particularly effective at removing mass under the site-specific conditions and because the process introduces large amounts of oxygen that reduce the expression of natural attenuation process.

Decision to perform additional SVE could be based on technical analysis of past operational data and any recent soil gas data and rebound studies.

\subsection{Continue Operation of groundwater P\&T (Groundwater source)}

Operation of the P\&T system provided removal of VOCs from groundwater zone in the OU1 area. Concentrations decreased during operation and mass extraction rates at the end of operations were approximately $0.002 \mathrm{Kg} /$ day (about $0.001 \mathrm{lb} /$ day). In terms of mass, the removal is much less significant than the SVE removal rates. Continued operation is viable but the effectiveness may be limited because current concentrations are low. Past operation removed only a few pounds and concentrations at present time are lower then historical levels. System does reduce migration however and contain plume. Decision to perform additional groundwater pump and treat could be based on technical analysis of past operational data and any recent depth profile data. As with SVE, groundwater P\&T may impact biological degradation as it alters electron acceptor and donor migration in the subsurface.

Decision to perform additional groundwater P\&T should be based on technical analysis of past operational data and comparison to alternative strategies. 


\subsection{Monitored Natural Attenuation}

A preliminary analysis of MNA lines of evidence indicated that MNA processes are active at the OU-1 site. Key lines of evidence from this preliminary "back of the envelope" analysis are:

- Decreasing Concentrations. Fifteen wells with concentration vs. time data before the pump-and-treat system was installed were examined for trends by performing a subjective analysis of available concentration vs. time graphs. Of these 15 wells, only 10 had enough data and exhibited concentrations that were generally above detection limits. Of the 10 remaining wells, 5 showed an apparent decreasing trend from the start of sampling (typically 1993 or 1994) to early 1997 (when the pump-and-treat system was started). Of the remaining five wells, four had "no trend" and one had a possible increasing trend.

- Presence of Degradation Products. VOC monitoring data show the presence of daughter productions such as cis-DCE and vinyl chloride.

- Geochemical Footprints Observed. Geochemical data show scatter, but some wells show low dissolved oxygen levels that are amenable to anaerobic biodegradation.

- Possible Truncated Plume. An analysis of the theoretical plume length (defined as the seepage velocity times the time elapsed since the source became active) vs. the actual plume length (defined as the farthest down gradient expression of the plume) indicates that natural attenuation processes may have been successful at preventing the extensive migration of the plume, or ii) the plume has been captured by the production wells. The theoretical plume length was estimated at $\sim 35,000 \mathrm{ft}$ (1100 $\mathrm{ft} / \mathrm{yr}$ seepage velocity and an elapsed time of 34 years, 1970 to 2003). The available data indicate the actual plume length is likely to be less than $2000 \mathrm{ft}$ (based on data from well P46). This analysis is not conclusive as plume capture by the production wells can also explain the relatively short plume.

- Common Characteristics with Other MNA Sites. The plume has many of the characteristics of other chlorinated solvent plumes that are now being successfully managed by MNA (as indicated by the DOE historical survey, McGuire et al., 2004):

o Parent Compound. The parent compounds at OU-1 are PCE and TCE. These two parent compounds were found at $36 \%$ and $47 \%$ of sites undergoing treatment by MNA, respectively.

o Source Strength. The source strength (maximum observed concentration at the beginning of MNA) at OU-1 is less than $30 \mathrm{ppb}$. Approximately $98 \%$ of sites undergoing treatment by MNA have source strengths greater than 30 ppb.

o Plume Length. The estimated plume length at OU-1 is less than $1500 \mathrm{ft}$. Approximately half of sites undergoing treatment by MNA have longer plume lengths. 
o Groundwater Seepage Velocity. The estimated groundwater seepage velocity at OU-1 is $1100 \mathrm{ft} / \mathrm{yr}$. While this is relatively fast compared to most sites, the DOE historical survey reported that $12 \%$ of sites undergoing treatment by MNA had seepage velocities greater than $200 \mathrm{ft} / \mathrm{yr}$.

In summary, the preliminary analysis indicates that MNA is a potential cleanup technology. However, several factors complicate the analysis:

- Operation of the extraction wells (pump-and-treat system) from 1997 to 2003. This has had the effect of changing the flow direction and potentially altering the geochemical conditions at the site (i.e., the extraction wells may have drawn oxygenated water into previously anaerobic zones).

- Operation of the plant production wells. This may have had the effect of making the general groundwater flow direction to the south and not the southwest (potentially the natural groundwater flow direction in the vicinity of OU-1). If the groundwater flow direction does change direction to the southwest after suspending operation of the production wells, the effective treatment zone for MNA processes may be reduced from $>700 \mathrm{ft}$ (the distance from the extraction wells to the southernmost production well) to only $60 \mathrm{ft}$ (the distance from the extraction wells to the plant boundary to the southwest).

Additional analysis work would be required to fully evaluate MNA as a potential cleanup technology. The tasks outlined in the site characterization section would need to be performed to complete the MNA assessment.

\subsection{Biostimulation}

Anaerobic bioremediation is a well-proven technology in which anaerobic microorganisms degrade chlorinated solvents by the mechanism of reductive dehalogenation (Figure 1). The pathway for this mechanism includes the degradation intermediates dichloroethene, vinyl chloride and ethene. There is data from groundwater wells at the site in recent history that these degradation products were present. This microbial activity requires strongly anaerobic conditions and the presence of anaerobic microorganisms possessing reductive dehalogenation capability. In cases where natural conditions do not support active anaerobic reductive dehalogenation, it is common to deploy biostimulation (addition of carbon sources to produce anaerobic conditions) as well as bioaugmentation (addition of anaerobic halorespiring bacteria) to achieve in situ anaerobic biodegradation of chlorinated solvents. Correct conditions and the presence of appropriate biocatalysts will commonly result in complete degradation of chlorinated solvents. 


\section{Reductive Dechlorination of TCE}

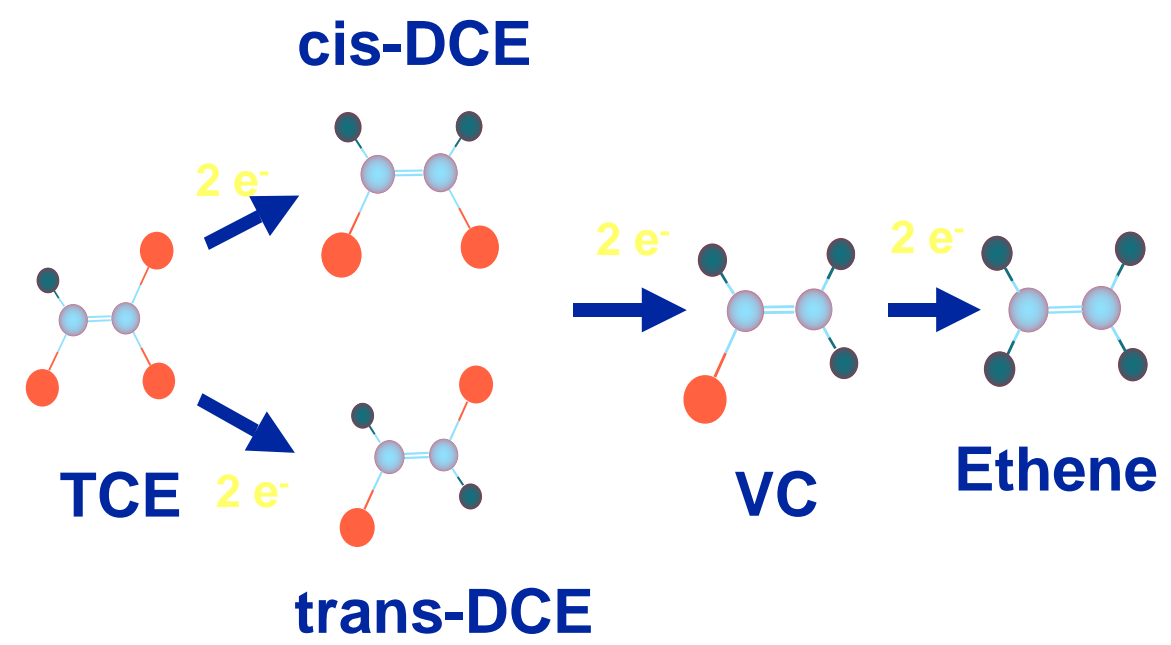

Figure 5-1. Pathway for stepwise reductive dechlorination of Trichloroethylene.

Application of anaerobic bioremediation for in situ treatment of contaminated soils at Mound would require that strong anaerobic conditions be established and maintained. This could be done by exclusion of oxygen, but more likely by biostimulation with excess organic nutrient supplementation. Because halorespiring bacteria can use chlorinated ethenes as terminal electron acceptors in order to gain energy, the environment must first be depleted of all other potential terminal electron acceptors with higher energy levels, e.g. nitrate and sulfate (Figure 3). The halorespirers like Dehalicoccoides ethogenes are one of the few organisms that degrade Tetrachloroethylene (PCE) and TCE all the way to ethene, via stepwise reductive dechlorination. However, some sites are known to go into what is referred to as a 'stall' where reductive dechlorination stops at either cis-DCE or vinyl chloride. Usually this stall is caused by lack of halorespirers, or high concentrations of competing terminal electron acceptors. Additionally, the bioprocess conditions would need to be held within acceptable ranges for temperature, $\mathrm{pH}$, and moisture. Macronutrient additions (primarily nitrogen and phosphorous) may also be required. For in situ biostimulation at the OU-1 in the source area the greatest problem will be the low concentration of contaminants, high concentrations of sulfate, and the low concentrations of electron donor as indicated by the low concentrations of organic carbon in the ground water. Hydraulic conductivities of $10^{-4}-10^{-7} \mathrm{~cm} / \mathrm{sec}$ are minimally acceptable for any type of liquid injection. The Mound site generally shows HC $>10^{-4} \mathrm{~cm} / \mathrm{sec}$ in the BVA. Initial analysis of the data from OU-1 suggests that biodegradation activity may be low as indicated by the presence of oxygen, low carbon, and potentially high sulfate. Further characterization may suggest that biostimulation is necessary with electron donors.

A number of carbon compounds can act as electron donors to drive anaerobic processes, for more discussion see the section below on carbon amendments. The mechanism is similar for 
all of the potential carbon sources that could be used, but none are as simple as lactate. HRC (hydrogen release compound) has already been injected at the Ashtabula site and was a good choice as an electron donor for biostimulation of indigenous microbes. HRC is a polylactate compound that slowly releases lactate when mixed with water. The released lactic acid stimulates both aerobic and anaerobic microbes by providing a carbon and energy source. Anaerobic microbes ferment the lactic acid into pyruvic acid and then to acetic acid, releasing 2 moles of molecular hydrogen per mole of lactate. Investigations conducted by Regenesis, Ltd. showed that the slow release characteristics of HRC cause reducing conditions to be maintained for a long time (up to 18 months) with a single HRC application. This is a cost effective aquifer treatment as compared to other remediation technologies, in aquifers where it is applicable and time is not a constraint.

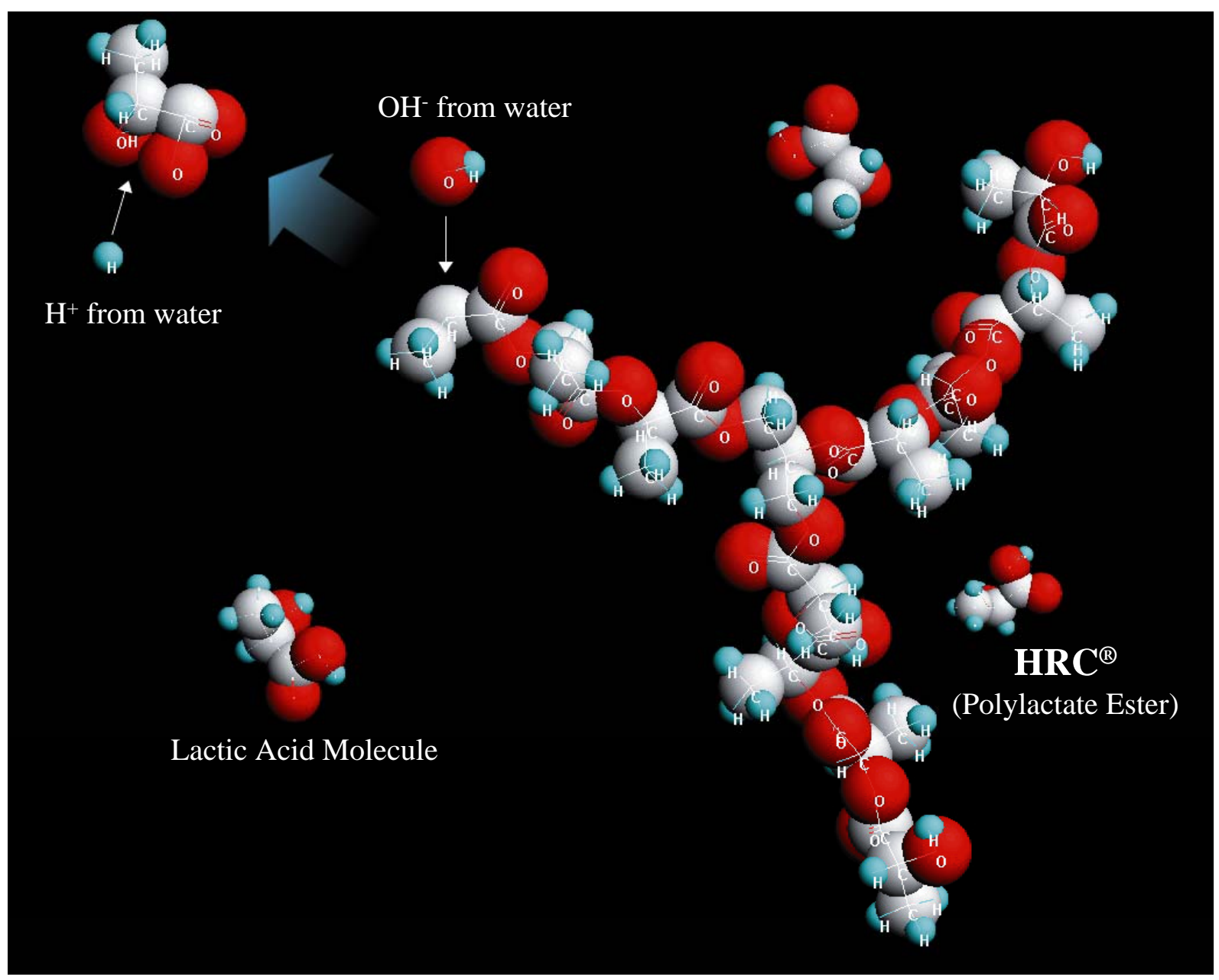

Figure 5-2. The polylactate ester structure of HRC and it's solubilization in water.

Since it is possible that indigenous microbial populations under anaerobic conditions may not degrade chlorinated solvents or only partially degrade them. The past detection of undegraded chlorinated solvent intermediates (e. g., cis-DCE and vinyl chloride) in groundwater at OU-1 indicates this may be problematic. Partial microbial degradation could 
result in significant production of degradation intermediates. Anaerobic microorganisms typically grow slowly and the time required to get to a reasonable cleanup goal could be excessive. During implementation of the bioremediation project at Ashtabula, a contingency was developed to address problems regarding the buildup of intermediates such as cis-DCE and vinyl chloride. SEC and Regenesis believe it is very unlikely that any buildup will occur based on previous experience in similar geology. However, they did include a contingency to utilize Oxygen Release Compound (ORC) to force the system aerobic and promote the rapid breakdown of the intermediates in situ, if necessary. The aerobic conditions would also be subject to the same nutrient limitations as the anaerobic environment. Aerobic cometabolic biostimulation is unlikely to be an effective strategy in the fast flowing ground water environment of OU-1. This type of biostimulation would require injection of electron donor and air or oxygen. This would necessitate too many injection points or horizontal well injection, both of which would be probably cost prohibitive.

In situ bioremediation of TCE has also been performed at Rocky Flats using HRC. Rocky Flats also experienced an initial lag and reduced rates of TCE reduction during the first 18 months (TIE, 2001, 2002). In this case they had more sulfate present then they originally anticipated and had to use more HRC to deplete the sulfate that was present. HRC-X has a slower release that would help maintain stronger reducing conditions for a longer period and may be an acceptable long-term strategy as long as sulfate could be depleted and was not constantly being resupplied from bedrock sources.

Unfortunately, the efficacy of in situ biostimulation and MNA is inconclusive at this point. Additional groundwater and soil sampling is necessary to see if the soil PCE/TCE can be biodegraded and that DCE, VC, and ethene have and will increase in the ground water, concomitant with declines in sulfate, oxygen, and nitrate. Better techniques for oxygen and redox measurements also need to be tried, and more attention to TOC analysis as an indicator of electron donor availability. A few measurements for Dehalicoccoides using real-time PCR would also help to verify that the organisms that can completely reduce TCE are present and active.

HRC-X would be a good long-term choice once reducing conditions for both TCE and PCE had been established, since it lasts for up to 3 years and would maintain reducing conditions with only an every other year or so injection. If only sodium lactate was used instead of HRC the cost would be $\$ 35 \mathrm{~K}-105 \mathrm{~K}$ for the lactate, but could require at least twice annual injections. Given the low concentrations at this site, biostimulation using the correct electron donor might be able to be performed as an EPR and considered sustainable. 


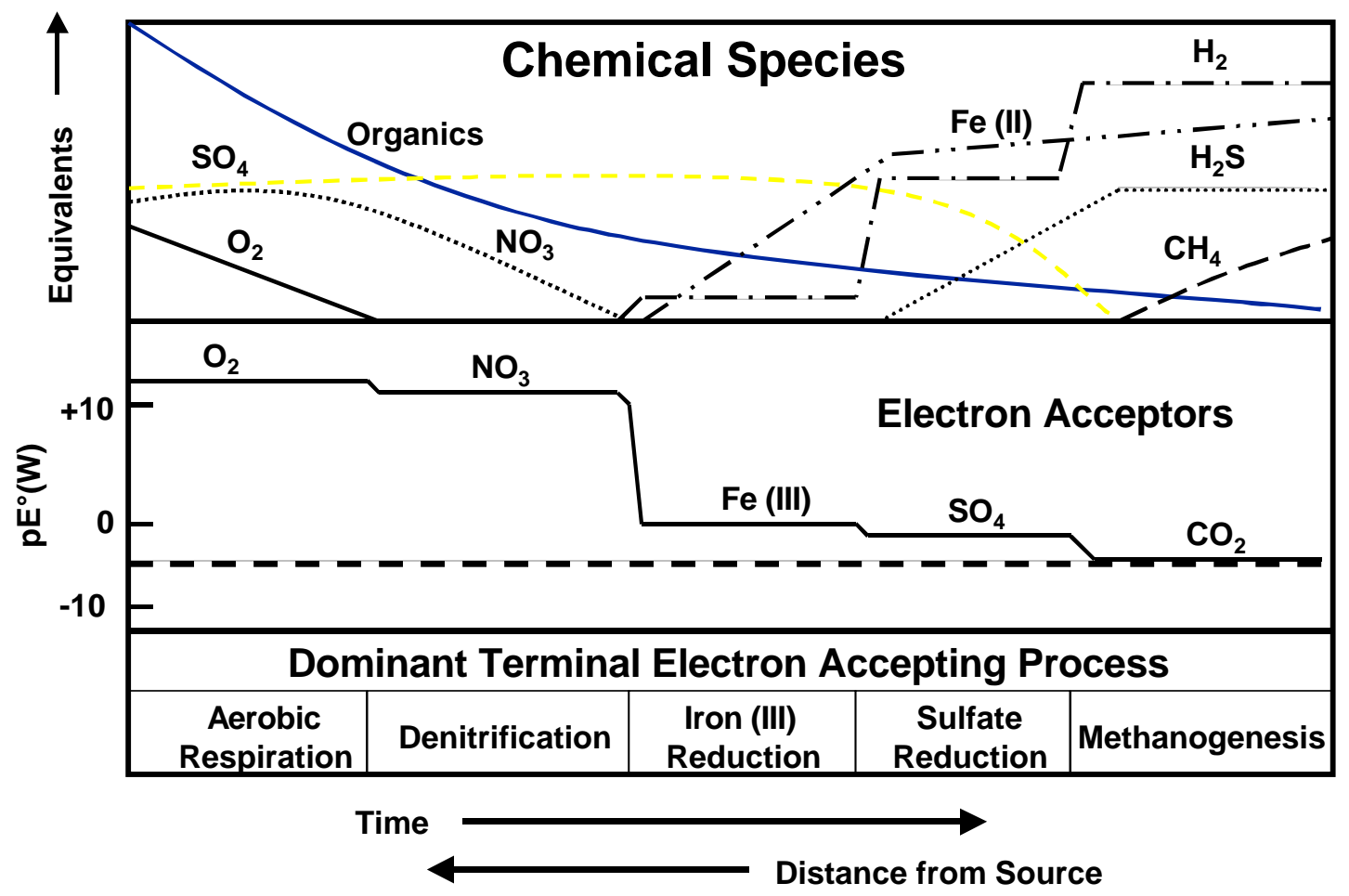

Figure 5-3. Critical chemical species, electron acceptors, and redox processes in relationship to bounding conditions necessary for reductive dechlorination of TCE (dashed line). 


\subsection{Partitioning Barrier}

Food grade oils, such as soybean oil, have low water solubility and are less dense than water. Similar to the electron donors discussed above, soybean oil can support environmental cleanup of chlorinated solvents such as trichloroethylene (TCE) when deployed in the subsurface. Soybean oil can promote the remediation of TCE groundwater plumes, such as the MCP OU-1 plume, by:

- providing a carbon source/electron donor for microbially mediated anaerobic degradation, and

- providing a barrier to physically isolate and mitigate TCE transport due to preferential partitioning into the oil phase.

Past environmental studies of soybean oil and related natural oils have focused primarily on microbial objectives, with limited emphasis on the benefits associated with partitioning. A more balanced technical approach, emphasizing partitioning, has the potential to facilitate the implementation of soybean oil based remediation. Expediting field deployment of soybean oil based on barrier/isolation objectives would accelerate cleanup and allow field measurement of bioremediation performance, bypassing some of the extensive and costly site-specific laboratory testing that is typically performed. DOE scientists have recently recommended emphasizing partitioning as an alternative conceptual basis for design.

As discussed above, the introduction of a carbon source/electron donor and related nutrients (biostimulation) into the subsurface has shown significant promise for the remediation of chlorinated solvents such as TCE in soil and groundwater in laboratory studies and limited field deployments. The carbon source/electron donors are often organic amendments delivered as aqueous solutions (containing lactate, molasses, or similar compounds), proprietary polymerized organics (such as Hydrogen Release Compound), nontoxic oils (such as soybean oil, lard oil, etc.), and blended amendments (such as water-oil emulsions). This partitioning barrier concept specifically addresses strategies and potential benefits associated with deployment of nontoxic oils. These benefits result from the unique characteristics of these oils and how these characteristics can be utilized advantageously in deployment to meet specific goals.

An impediment to the use of in situ bioremediation is the current implementation approach that typically requires significant site-specific investment in laboratory microbiological design prior to approval and deployment. While some level of site-specific microbial study is essential, the current lab-centric focus does not effectively address the critical challenges of field scale deployment. Large investments in laboratory studies prior to deployment are often of limited value because the field-scale performance and behavior may not be adequately predicted by the micro and mesoscale experimentation. Further, non-microbial benefits of the actions have received limited attention. As shown below, understanding and predicting non-microbial performance may be a key factor in facilitating and accelerating cost effective deployment of nontoxic oils for remediation. Accelerated deployment of the oils would support long-term bioremediation objectives because it would allow cost-effective field-scale confirmation and quantification. 
In addition to providing a carbon source/electron donor, separate phase organics such as soybean oil provide a medium into which chlorinated solvents such as TCE preferentially partition. Where deployed in the subsurface, soybean oil results in the depression of TCE concentrations in nearby groundwater (and soil gas). The actual concentrations can be calculated using partition coefficients and/or Raoult's Law. Because of the simple conceptual basis, the deployment can be designed to physically isolate the source material from the plume and essentially eliminate the flux from the source.

If bioaugmentation for the anaerobic declorination of TCE to ethene is needed at a site, it typically involves the injection of commercially available mixed cultures containing Dehalococcoides populations. These populations are sensitive to oxygen and they require anaerobic conditions. Even if site-specific laboratory testing is utilized to determine whether bioaugmentation is needed, the carbon source/electron donor is typically injected prior to the Dehalococcoides populations to establish favorable conditions first. Proceeding to field deployment based on partitioning objectives would provide an environment suitable for native halorespiring bacteria to increase and may reduce the laboratory testing needed. Actual populations could be monitored from real-world samples and a clear basis for bioaumentation needs developed. The soybean oil will provide TCE isolation for an extended period of time and allow field-scale verification of bioremediation using costeffective techniques such as in situ respirometry. As in traditional in situ bioremediation, confirmation and quantification of the rate of biological contaminant destruction is the longterm basis for no further action. This confirmation/quantification is accelerated and made possible by the initial deployment of soybean oil for stabilization of the site. If field evaluation indicates that bioaugmentation is needed, the site will have developed appropriate conditions for the follow-on activity.

The figure below outlines the concepts of this proposal for a simple vadose-groundwater barrier scenario. Note that the diagram shown is highly simplified and variations are possible based on local conditions. At MCP OU-1 a deployment based on injection both above and below the water table would be appropriate because of the geometry of the site and geology.

Unfortunately, this is an untested approach and the efficacy of a partitioning barrier is inconclusive at this point. The principles for application have not been used in practice. Because of its lack of maturity and lack of case study support, stakeholders and regulators may not accept this approach. Further, implementation of this type of system would adversely impact the performance of some of the other potential remedial action technologies (e.g., would reduce the effectiveness of further pump and treat or SVE) and the action is not reversible. Thus, if used in a treatment sequence, all of the other type of activity would need to be completed prior to implementation. Given the low contaminant concentrations at this site, a partitioning barrier might be able to be performed as an EPR and considered sustainable. If this concept were selected for further analysis, site specific calculation and some additional sampling would be needed. If implemented some of the analyses described for biostimulation would be appropriate and necessary. While the team found this concept intriguing and potentially viable, it was not recommended due to its lack of past use/experience. 


\subsection{Hydrologic Modification}

As described in the characterization section, shutdown of the plant production wells may change the groundwater flow pattern in the OU-1 area. If groundwater in OU-does change and flows to the southwest as hypothesized then naturally-occurring attenuation processes may not be vigorous enough to attenuate the plume before it goes off-site (e.g., the plant boundary is only $\sim 50$ feet to the west of the current OU-1 plume). However, there is a much larger area where natural attenuation processes could be utilized directly south of OU-1. This area has the advantage of being entirely within Mound Plant boundaries.

Pumping clean water from one or more of the existing plant production wells could be used to provide a hydrologic modification that would maintain a southerly flow direction in OU1. With this modification, there would be approximately $700 \mathrm{ft}$ of potential area for treatment of the OU-1 plumes by natural processes.

To make this alternative viable, this hydrologic modification would likely subject to a number of conditions. Some possible conditions are listed below:

- Pumping of the production wells would not be a permanent measure as natural attenuation processes would be expected to eventually remediate the plume.

- Concentrations of site constituents in the production wells would have to be low enough so that treatment would not be needed.

- The cause of the increasing concentrations in production well 0076 would have to be understood, and the mechanism that is causing this increasing trend would not persist or could be managed in some way.

- Attenuation processes would have to be strong enough to reduce concentrations of site constituents in the area of the extraction wells to very low concentrations before reaching the active production wells.

- The clean water pumped from the production wells could be discharged to surface water.

Key tasks required to implement this alternative would likely include some or all of the following tasks:

Complete Delineation of Plume Near P046. Concentrations of TCE have increased in well P046 from 1-3 $\mu \mathrm{g} / \mathrm{L}$ to nearly $8 \mu \mathrm{g} / \mathrm{L}$ since spring 1999 . Since this well is located near the southernmost plant production well (P046 is $\sim 100$ to the east of production well 76 )), the origin of the TCE in this area and the cause of the increasing concentrations need to be understood. A direct-push investigation to collect additional groundwater data in this area would be performed to delineate the TCE plume in this area. In addition, a hydraulic evaluation would be performed to evaluate the hypothesis that the increasing concentrations are related to lower pumping rates in production well 76. 
Apply Computer Model to Evaluate Assimilative Capacity. A natural attenuation model would be used to estimate if the treatment zone (located between the south end of OU-1 and the production wells used for the hydrologic modification) would be able to reduce plume concentrations to acceptable levels before reaching the production wells.

Apply Existing Groundwater Flow Model. The existing MODFLOW model of the OU-1 buried valley aquifer system would be used to simulate the change (if any) in groundwater flow direction due to suspension of pumping of the extraction wells and plant production wells. The model would be used to determine which wells would need to be pumped and what pumping rate would be required. Groundwater velocity data can be developed using hydraulic conductivity data and the hydraulic gradient data derived from the potentiometric surface maps. 


\subsection{Waste Removal/Excavation}

Physical removal of the contaminated source material would reduce or eliminate flux of VOCs to the groundwater if all sources were removed. The effectiveness of this strategy would be high if all of the contaminated soil and materials could be identified and were in our near the landfill removal area. The cocooned wastes are similar to the underlying and surrounding soils and the clay barrier was constructed of soil from the same area. The locations of all the VOC sources are not known and may lie under the overflow pond and cocoon. There is significant risk of not removing all of the VOC sources currently loading the ground water. This excavation is likely to require removal of the overflow pond and the surrounding sediments and fairly deep into the vadose zone to make sure all VOC sources have been removed. In 1994, it was estimated that the landfill excavation would require removal of 1.6 million $\mathrm{ft}^{3}$ of material and an additional 1.4 million $\mathrm{ft}^{3}$ of fill around the landfill (OU-1 Feasibility Report, 1994). Excavation of material around the pond could easily include another 2 million $\mathrm{ft}^{3}$. The estimate of removal costs for the landfill alone was $\$ 23.4$ million. With the addition of the pond excavation and surrounding sediment it the total cost could easily exceed $\$ 35$ million. The advantage of excavation of the entire area would be the potential of removal of all VOC sources and the elimination of any future liability from any components in the landfill waste that was disposed of in the OU-1 area. Excavation of this area would also potentially increase the land uses for the area by allowing greater building options.

Excavation and removal is not recommended based on VOCs alone because VOCs in the ground water are near the target levels and alternative strategies provide similar performance for a small fraction of the costs. 


\subsection{Technology Combinations}

Based on the information in the matrix, no single technology or approach represents and complete and optimum action. Rather, the team recommended blending technologies into viable combinations and evaluating the overall costs and benefits of the combinations. In general, a combination comprises technology(-ies) as needed to address the residual flux from the source/vadose zone, and technology(-ies) to address the groundwater plume in a reasonable time frame. In the following lists, the technologies are qualitatively arranged in order of preference based on the technology matrix evaluation. Examples viable technologies:

- for addressing residual vadose zone "source" contamination/flux (if necessary) - SVE, biostimulation/partitioning barrier

- for addressing residual shallow water table "source" contamination/flux (if necessary) MNA, biostimulation/partitioning barrier, $\mathrm{P} \& \mathrm{~T}$

- for addressing the groundwater plume - MNA, biostimulation/partitioning barrier, P\&T

- for consideration in combination with all actions - hydrologic modification

Thus a typical-reasonable combination might be additional SVE (if necessary) until mass removal and rebound criteria are met, combined with precisely targeted biostimulation and MNA.

The specific combination that should be selected should be based on the characterization results. Some of the methods may not be justified if the data indicate that source VOC has been effectively addressed by previous efforts (e.g., continued P\&T or continued SVE). "No further action" was considered a longer term end-state goal of other actions rather than a near term strategy. Large scale waste removal, while viable, was generally not recommended. 


\begin{tabular}{|c|c|c|c|c|c|c|c|c|c|}
\hline $\begin{array}{l}\text { Cleanup } \\
\text { Technology / } \\
\text { Strategy } \\
\end{array}$ & Objectives & Effectiveness* & $\begin{array}{l}\text { Regulatory } \\
\text { and Public } \\
\text { Acceptability } \\
\end{array}$ & Implementability & Schedule & Cost** & $\begin{array}{l}\text { Long term } \\
\text { Perfomance }\end{array}$ & $\begin{array}{l}\text { Technical } \\
\text { Maturity }\end{array}$ & Overall \\
\hline $\begin{array}{l}\text { "No Further } \\
\text { Action" }\end{array}$ & $\begin{array}{l}\text { Determination } \\
\text { that existing } \\
\text { low } \\
\text { concentrations } \\
\text { pose little or } \\
\text { no risk }\end{array}$ & $\begin{array}{l}\text { Provide limited } \\
\text { additional } \\
\text { performance } \\
\text { (although natural } \\
\text { attenuation } \\
\text { processes will occur } \\
\text { even if not } \\
\text { monitored). Unless } \\
\text { monitored, near } \\
\text { term and } \\
\text { intermediate term } \\
\text { impacts will not be } \\
\text { detected. }\end{array}$ & $\begin{array}{l}\text { Limited - } \\
\text { current } \\
\text { groundwater } \\
\text { concentration } \\
\text { are above } \\
\text { typical MCL } \\
\text { based criteria } \\
\text { in some wells. }\end{array}$ & $\begin{array}{l}\text { Low - burden of } \\
\text { proof is } \\
\text { challenging }\end{array}$ & Rapid & $\begin{array}{l}\text { Initial - Low } \\
\text { to Medium } \\
\text { O\&M - zero } \\
\text { May require } \\
\text { significantly } \\
\text { more initial } \\
\text { data, } \\
\text { verification } \\
\text { data, and } \\
\text { modeling to } \\
\text { achieve } \\
\text { acceptance. }\end{array}$ & Unknown & $\begin{array}{l}\text { Not } \\
\text { applicable }\end{array}$ & $\begin{array}{l}\text { Technically } \\
\text { viable - VOC } \\
\text { concentrations } \\
\text { are low and } \\
\text { team believes } \\
\text { that current } \\
\text { levels pose } \\
\text { little risk. } \\
\text { Other } \\
\text { alternatives } \\
\text { (combination } \\
\text { of MNA with } \\
\text { limited } \\
\text { treatment } \\
\text { actions) may } \\
\text { be better } \\
\text { because of } \\
\text { higher } \\
\text { confidence. } \\
\text { This is final } \\
\text { stage of all } \\
\text { remediation } \\
\text { strategies. } \\
\text { Because of } \\
\text { low current } \\
\text { concentration, } \\
\text { team } \\
\text { recommends } \\
\text { considering } \\
\text { alternative risk } \\
\text { based } \\
\text { concentration } \\
\text { criteria for all } \\
\text { options. }\end{array}$ \\
\hline SVE & $\begin{array}{l}\text { Continued } \\
\text { removal of } \\
\text { residual VOC }\end{array}$ & $\begin{array}{l}\text { Limited because } \\
\text { system has operated } \\
\text { and removed much }\end{array}$ & High & High & Rapid & $\begin{array}{l}\text { Initial -Low } \\
\text { O\&M - }\end{array}$ & $\begin{array}{l}\text { Limited - } \\
\text { may not } \\
\text { provide }\end{array}$ & Mature & $\begin{array}{l}\text { Viable }- \text { not } \\
\text { recommended } \\
\text { unless further }\end{array}$ \\
\hline
\end{tabular}




\begin{tabular}{|c|c|c|c|c|c|c|c|c|c|}
\hline $\begin{array}{l}\text { Cleanup } \\
\text { Technology / } \\
\text { Strategy }\end{array}$ & Objectives & Effectiveness* & $\begin{array}{l}\text { Regulatory } \\
\text { and Public } \\
\text { Acceptability }\end{array}$ & Implementability & Schedule & Cost** & $\begin{array}{l}\text { Long term } \\
\text { Perfomance }\end{array}$ & $\begin{array}{l}\text { Technical } \\
\text { Maturity }\end{array}$ & Overall \\
\hline & $\begin{array}{l}\text { source from } \\
\text { vadose zone. }\end{array}$ & $\begin{array}{l}\text { of the easily } \\
\text { accessible VOC. } \\
\text { Removal of VOC } \\
\text { from vadose zone is } \\
\text { much easier and less } \\
\text { expensive than } \\
\text { removal once } \\
\text { leached into } \\
\text { groundwater. } \\
\text { Decision to perform } \\
\text { additional SVE } \\
\text { could be based on } \\
\text { technical analysis of } \\
\text { past operational data } \\
\text { and any recent soil } \\
\text { gas data and } \\
\text { rebound studies. }\end{array}$ & & & & Low & $\begin{array}{l}\text { significant } \\
\text { additional } \\
\text { benefit since } \\
\text { past operation } \\
\text { have removed } \\
\text { most of the } \\
\text { available } \\
\text { target VOC }\end{array}$ & & $\begin{array}{l}\text { data warrants } \\
\text { additional } \\
\text { operation. }\end{array}$ \\
\hline $\begin{array}{l}\text { Pump and } \\
\text { Treat }\end{array}$ & $\begin{array}{l}\text { Continued } \\
\text { removal of } \\
\text { residual VOC } \\
\text { source from } \\
\text { groundwater. } \\
\text { Containment } \\
\text { of low } \\
\text { concentration } \\
\text { VOC plume. }\end{array}$ & $\begin{array}{l}\text { Limited because } \\
\text { concentrations are } \\
\text { low. Past operation } \\
\text { removed only a few } \\
\text { lbs and } \\
\text { concentrations at } \\
\text { present time are } \\
\text { lower then historical } \\
\text { levels. System does } \\
\text { reduce migration } \\
\text { however and contain } \\
\text { plume. Decision to } \\
\text { perform additional } \\
\text { groundwater pump } \\
\text { and treat could be } \\
\text { based on technical } \\
\text { analysis of past } \\
\text { operational data and } \\
\text { any recent depth }\end{array}$ & High & High & Rapid & $\begin{array}{l}\text { Initial -Low } \\
\text { O\&M - } \\
\text { moderate }\end{array}$ & $\begin{array}{l}\text { Limited - } \\
\text { may not } \\
\text { provide } \\
\text { significant } \\
\text { additional } \\
\text { benefit since } \\
\text { past operation } \\
\text { have removed } \\
\text { most of the } \\
\text { available } \\
\text { target VOC. }\end{array}$ & Mature & $\begin{array}{l}\text { Viable - not } \\
\text { recommended } \\
\text { unless further } \\
\text { data warrants } \\
\text { additional } \\
\text { operation } \\
\text { and/or plume } \\
\text { containment is } \\
\text { necessary. } \\
\text { May be useful } \\
\text { in combination } \\
\text { with other } \\
\text { actions if P\&T } \\
\text { does not } \\
\text { adversely } \\
\text { impact overall } \\
\text { performance. }\end{array}$ \\
\hline
\end{tabular}


Groundwater Strategy for the OU-1 Landfill Area,

WSRC-TR-2004-00148

Miamisburg Closure Project, Ohio page 59 of 74

\begin{tabular}{|c|c|c|c|c|c|c|c|c|c|}
\hline $\begin{array}{l}\text { Cleanup } \\
\text { Technology / } \\
\text { Strategy }\end{array}$ & Objectives & Effectiveness* & $\begin{array}{l}\text { Regulatory } \\
\text { and Public } \\
\text { Acceptability }\end{array}$ & Implementability & Schedule & Cost** & $\begin{array}{l}\text { Long term } \\
\text { Perfomance }\end{array}$ & $\begin{array}{l}\text { Technical } \\
\text { Maturity }\end{array}$ & Overall \\
\hline & & $\begin{array}{l}\text { profile data. May } \\
\text { impact biological } \\
\text { degradation if it } \\
\text { alters electron } \\
\text { acceptor and donor } \\
\text { in the subsurface. }\end{array}$ & & & & & & & \\
\hline $\begin{array}{l}\text { Natural } \\
\text { Attenuation }\end{array}$ & $\begin{array}{l}\text { Utilize natural } \\
\text { attenuation } \\
\text { mechanisms in } \\
\text { soil and } \\
\text { groundwater } \\
\text { system to } \\
\text { remediate } \\
\text { contamination } \\
\text { at a rate that } \\
\text { balances the } \\
\text { residual source } \\
\text { flux. Process } \\
\text { results in a } \\
\text { stable or } \\
\text { shrinking } \\
\text { plume. }\end{array}$ & $\begin{array}{l}\text { Historically, the } \\
\text { OU1 system has } \\
\text { exhibited } \\
\text { indications of } \\
\text { attenuation (such as } \\
\text { daughter products) } \\
\text { but plume stability } \\
\text { has not been } \\
\text { documented. } \\
\text { Impacts of SVE and } \\
\text { P\&T operation and } \\
\text { other planned } \\
\text { activities such as } \\
\text { discontinuing } \\
\text { production well } \\
\text { operation need to be } \\
\text { assessed. }\end{array}$ & $\begin{array}{l}\text { Moderate to } \\
\text { high if } \\
\text { properly } \\
\text { documented. } \\
\text { Similar sites } \\
\text { have been } \\
\text { successfully } \\
\text { addressed } \\
\text { using MNA in } \\
\text { the past several } \\
\text { years. }\end{array}$ & $\begin{array}{l}\text { High - if data } \\
\text { support } \\
\text { implementation }\end{array}$ & $\begin{array}{l}\text { Medium - } \\
\text { additional data } \\
\text { collection and } \\
\text { analysis required } \\
\text { for } \\
\text { implementation }\end{array}$ & $\begin{array}{l}\text { Initial -low } \\
\text { moderate } \\
\text { O\&M - low }\end{array}$ & Good & Moderate & $\begin{array}{l}\text { Potentially } \\
\text { viable - } \\
\text { recommended } \\
\text { if data support } \\
\text { use and } \\
\text { recommended } \\
\text { in combination } \\
\text { with other } \\
\text { actions if } \\
\text { attenuation not } \\
\text { sufficient to } \\
\text { stabilize } \\
\text { plume. }\end{array}$ \\
\hline Biostimulation & $\begin{array}{l}\text { Provide } \\
\text { amendments } \\
\text { such as } \\
\text { electron } \\
\text { donors to } \\
\text { stimulate } \\
\text { indigenous } \\
\text { microorganism } \\
\text { s to degrade } \\
\text { VOCs to target } \\
\text { levels. }\end{array}$ & $\begin{array}{l}\text { Process has been } \\
\text { successfully } \\
\text { demonstrated under } \\
\text { a variety of } \\
\text { conditions and } \\
\text { settings. Can be } \\
\text { performed either } \\
\text { aerobically or } \\
\text { anaerobically. } \\
\text { Depending on } \\
\text { amendments used, } \\
\text { system requires }\end{array}$ & $\begin{array}{l}\text { Medium to } \\
\text { high - } \\
\text { particularly for } \\
\text { slow release } \\
\text { amendments } \\
\text { (e.g., HRCX). }\end{array}$ & Medium & Medium & $\begin{array}{l}\begin{array}{l}\text { Initial - low } \\
\text { to medium }\end{array} \\
\mathrm{M} \& \mathrm{O} \text { - low }\end{array}$ & Good & High & $\begin{array}{l}\text { Viable - } \\
\text { recommended } \\
\text { only if } \\
\text { something } \\
\text { more rigorous } \\
\text { than MNA is } \\
\text { needed. } \\
\text { Possible to use } \\
\text { in combination } \\
\text { with MNA, } \\
\text { hydrologic } \\
\text { modification }\end{array}$ \\
\hline
\end{tabular}


Groundwater Strategy for the OU-1 Landfill Area,

WSRC-TR-2004-00148

Miamisburg Closure Project, Ohio page 60 of 74

\begin{tabular}{|c|c|c|c|c|c|c|c|c|c|}
\hline $\begin{array}{l}\text { Cleanup } \\
\text { Technology / } \\
\text { Strategy }\end{array}$ & Objectives & Effectiveness* & $\begin{array}{l}\text { Regulatory } \\
\text { and Public } \\
\text { Acceptability }\end{array}$ & Implementability & Schedule & Cost** & $\begin{array}{l}\text { Long term } \\
\text { Perfomance }\end{array}$ & $\begin{array}{l}\text { Technical } \\
\text { Maturity }\end{array}$ & Overall \\
\hline & & $\begin{array}{l}\text { periodic reinjection } \\
\text { until targets are met. } \\
\text { Some amendments } \\
\text { provide longer } \\
\text { performance times } \\
\text { and are more } \\
\text { sustainable. Slower } \\
\text { release processes } \\
\text { may be needed for } \\
\text { this site. }\end{array}$ & & & & & & & $\begin{array}{l}\text { and other } \\
\text { activities. }\end{array}$ \\
\hline $\begin{array}{l}\text { Partitioning } \\
\text { Barrier }\end{array}$ & $\begin{array}{l}\text { Install long- } \\
\text { lived nontoxic } \\
\text { hydrocarbon } \\
\text { such as } \\
\text { soybean oil in } \\
\text { the form of a } \\
\text { downgradient } \\
\text { barrier. Low } \\
\text { concentration } \\
\text { groundwater } \\
\text { flows through } \\
\text { barrier and } \\
\text { contaminant } \\
\text { partitions into } \\
\text { oil resulting in } \\
\text { water that } \\
\text { meets target } \\
\text { levels. Barrier } \\
\text { has additional } \\
\text { benefit of } \\
\text { providing } \\
\text { environment } \\
\text { that is well } \\
\text { suited to } \\
\text { biodegradation }\end{array}$ & $\begin{array}{l}\text { Immature concept. } \\
\text { Relies on well } \\
\text { documented } \\
\text { partitioning, but } \\
\text { requires controlled } \\
\text { installation of } \\
\text { hydrocarbon barrier. } \\
\text { May be difficult to } \\
\text { control barrier } \\
\text { geometry in high } \\
\text { permeability BVA. } \\
\text { Oil barrier reduces } \\
\text { hydraulic } \\
\text { conductivity. } \\
\text { Uncertainties may } \\
\text { increase costs. } \\
\text { Geometry of barrier } \\
\text { and knowledge of } \\
\text { flow paths are } \\
\text { critical to success. }\end{array}$ & $\begin{array}{l}\text { Moderate to } \\
\text { low - new } \\
\text { concept }\end{array}$ & $\begin{array}{l}\text { Moderate - new } \\
\text { concept }\end{array}$ & Moderate & $\begin{array}{l}\text { Low to } \\
\text { moderate }\end{array}$ & $\begin{array}{l}\text { Moderate to } \\
\text { high - long } \\
\text { term lifetime } \\
\text { uncertain - } \\
\text { may be only } \\
10 \text { or } 20 \text { years }\end{array}$ & $\begin{array}{l}\text { Low - new } \\
\text { concept }\end{array}$ & $\begin{array}{l}\text { Potentially } \\
\text { viable - } \\
\text { recommended } \\
\text { only if of } \\
\text { particular } \\
\text { benefit to } \\
\text { future site } \\
\text { configuration. } \\
\text { Alternative } \\
\text { technology, } \\
\text { biostimulation } \\
\text { are more } \\
\text { mature. }\end{array}$ \\
\hline & & & & & & & & & \\
\hline
\end{tabular}




\begin{tabular}{|c|c|c|c|c|c|c|c|c|c|}
\hline $\begin{array}{l}\text { Cleanup } \\
\text { Technology / } \\
\text { Strategy }\end{array}$ & Objectives & Effectiveness* & $\begin{array}{l}\text { Regulatory } \\
\text { and Public } \\
\text { Acceptability }\end{array}$ & Implementability & Schedule & Cost** & $\begin{array}{l}\text { Long term } \\
\text { Perfomance }\end{array}$ & $\begin{array}{l}\text { Technical } \\
\text { Maturity }\end{array}$ & Overall \\
\hline $\begin{array}{l}\text { Hydrologic } \\
\text { Modification } \\
\text { and Control }\end{array}$ & $\begin{array}{l}\text { Control the } \\
\text { plume } \\
\text { migration } \\
\text { pattern and } \\
\text { travel time to } \\
\text { maximize } \\
\text { natural } \\
\text { attenuation (or } \\
\text { other } \\
\text { destruction } \\
\text { processes) and } \\
\text { to minimize } \\
\text { offsite } \\
\text { transport. } \\
\end{array}$ & $\begin{array}{l}\text { As described in text, } \\
\text { requires active } \\
\text { pumping but no } \\
\text { water treatment. } \\
\text { Requires a good } \\
\text { model of hydrology } \\
\text { and of the } \\
\text { attenuation and } \\
\text { destruction } \\
\text { processes. }\end{array}$ & $\begin{array}{l}\text { Moderate } \\
\text { (alone) to high } \\
\text { (if used in } \\
\text { combination } \\
\text { with other } \\
\text { techniques) }\end{array}$ & Straightforward & Rapid & $\begin{array}{l}\text { Initial - low } \\
\text { O\&M - low }\end{array}$ & $\begin{array}{l}\text { Moderate } \\
\text { requires } \\
\text { commitement } \\
\text { of operation } \\
\text { for extended } \\
\text { period of time }\end{array}$ & high & $\begin{array}{l}\text { Viable - team } \\
\text { believed that } \\
\text { this is } \\
\text { applicable } \\
\text { only in } \\
\text { combination } \\
\text { with other } \\
\text { strategies }\end{array}$ \\
\hline $\begin{array}{l}\text { Waste removal } \\
\text { and excavation }\end{array}$ & $\begin{array}{l}\text { Physical } \\
\text { removal of } \\
\text { contaminated } \\
\text { source material } \\
\text { to reduce flux } \\
\text { of VOCs to } \\
\text { groundwater. }\end{array}$ & $\begin{array}{l}\text { High if source } \\
\text { material is identified } \\
\text { and removed. } \\
\text { Cocooned wastes } \\
\text { are similar to } \\
\text { surrounding soil and } \\
\text { debris. Clay barrier } \\
\text { is constructed of } \\
\text { excavated material } \\
\text { from the same area. } \\
\text { Locations of all } \\
\text { sources not } \\
\text { precisely known and } \\
\text { excavation likely to } \\
\text { require more than } \\
\text { just cocoon hill. } \\
\text { Significant risk of } \\
\text { not removing all of } \\
\text { the VOC source. }\end{array}$ & High & $\begin{array}{l}\text { Moderate - some } \\
\text { industrial and } \\
\text { transport risk to } \\
\text { workers. }\end{array}$ & $\begin{array}{l}\text { Moderate - } \\
\text { requires extensive } \\
\text { planning and } \\
\text { logistics }\end{array}$ & $\begin{array}{l}\text { Initial - } \\
\text { High } \\
\text { Highest } \\
\text { projected } \\
\text { initial costs } \\
\text { of evaluated } \\
\text { options. } \\
\text { M\&O - zero }\end{array}$ & Good & High & $\begin{array}{l}\text { Viable - not } \\
\text { recommended } \\
\text { based on } \\
\text { VOCs because } \\
\text { concentrations } \\
\text { are near target } \\
\text { levels and } \\
\text { alternatives } \\
\text { provide } \\
\text { similar } \\
\text { performance } \\
\text { for lower } \\
\text { costs. OU1 } \\
\text { PRSs that } \\
\text { have identified } \\
\text { risks are } \\
\text { already } \\
\text { scheduled for } \\
\text { removal } \\
\text { actions. }\end{array}$ \\
\hline
\end{tabular}




\subsection{CONCLUSIONS AND RECOMMENDATIONS}

The technical assistance team consisted of a diverse group of nationally recognized experts with expertise in hydrogeology, geochemistry, characterization, microbiology, remediation, dense non-aqueous phase liquids (DNAPLs) and natural attenuation. A principal consensus of the technical assistance team was that the concentrations of VOC in the groundwater underlying OU-1 are low (generally less than 20 to $30 \mu \mathrm{g} / \mathrm{L}$ (ppb) even after a period of rebound following SVE and P\&T). The team agrees that these levels of VOCs in the groundwater in this setting pose minimal risk. In general, groundwater concentrations have declined over time, both prior to and during the period of active remediation. Thus the team believes that the aggressiveness of the response action should be balanced and appropriate to the low concentrations at the site. Each of the individual remediation technologies examined by the team had positives and negatives, but none was ideal when used alone. Instead, a few combinations of technologies emerged as promising. Typically, the groupings of promising technologies consisted of limited action directed at the low levels of residual VOC being released into soil and groundwater ("sources" that remain after groundwater P\&T and SVE), supplemented by natural attenuation, monitoring and leading toward no further action. 


\section{REFERENCES}

Aziz, C.E., C.J. Newell, J.R. Gonzales, P. Haas, T.P. Clement, and Y. Sun, 1999. BIOCHLOR Natural Attenuation Decision Support System vers. 1.0 User's Manual. Air Force Center for Environmental Excellence, Brooks AFB, Texas. www.gsi-net.com

Aziz, J.J., C.J. Newell, H.S. Rifai, M.Ling, and J.R. Gonzales. 2000. Monitoring and Remediation Optimization System (MAROS) Software User's Guide, October 16, 2000. www.gsi-net.com.

Aziz, J.J.; Ling, M.; Rifai, H; Newell, C.J.; and Gonzales, J.R.. 2003. MAROS: a "Decision Support System for Optimizing Monitoring Plans", Ground Water, V41, No. 3, pp 355-367.

Barth, J. A. C., G. Slater, C. Schuth, M. Bill, A. Downey, M. Larkin, and R. M. Kalin. 2002. Carbon isotope fractionation during aerobic biodegradation of trichloroethene by Burkholderia cepacia G4: a tool to map degradation mechanisms. Applied and Environmental Microbiology 68:1728-1734.

Bowman, J. P., L. Jiménez, I. Rosario, T. C. Hazen, and G. S. Sayler. 1993. Characterization of the methanotrophic bacterial community present in a trichloroethylenecontaminated subsurface groundwater site. Applied and Environmental Microbiology. 59:2380-2387.

Istok, J.D., J.A. Field, M.H. Schroth, T.E. Sawyer, and M.D. Humphrey. 1999. Laboratory and Field Investigation of Surfactant Sorption Using Single-Well, "Push-Pull" Tests. Ground Water, Vol. 37, No. 4, pp. 589-598.

Löffler, F. E., Q. Sun, J. Li, and J. M. Tiedje. 2000. 16S rRNA Gene-Based Detection of Tetrachloroethene-Dechlorinating Desulfuromonas and Dehalococcoides Species. . Applied and Environmental Microbiology. 66:1369-3445.

McGuire, T.M., C.J. Newell, B.B. Looney, K.M. Vangelas. 2003. Performance of MNA Remedies at Chlorinated Solvent Sites, Savannah River Technology Center, Aiken, SC.

National Research Council, 2000. Natural Attenuation for Groundwater Remediation, National Academy Press, Washington, D.C.

Newell, C.J., H.S. Rifai, J.T. Wilson, J.A. Connor, J.A. Aziz, and M.P. Suarez. 2002. Calculation and Use of First-Order Rate Constants for Monitored Natural Attenuation, EPA Groundwater Issue Paper, EPA/540/S02/500, U.S. EPA, Ada, Oklahoma.

http://www.epa.gov/ada/pubs/issue/540S02500.html

Sayler, G. S., A. Layton, C. Lajoie, J. Bowman, M. Tschantz, and J. T. Fleming. 1995. Molecular site assessment and process monitoring in bioremediation and natural attenuation. Applied Biochemistry and Biotechnology 54:277-290. 
Song, D. L., M. E. Conrad, K. S. Sorenson, and L. Alvarez-Cohen. 2002. Stable carbon isotope fractionation during enhanced in situ bioremediation of trichloroethene.

Environmental Science \& Technology 36:2262-2268.

U S DOE,

U.S. Environmental Protection Agency. 1995. Bioventing Principles and Practices, Volume II: Bioventing Design. U. S. Evironmental Protection Agency. EPA/540/R-95/534b.

U.S. Environmental Protection Agency. 1999. Use of Monitored Natural Attenuation at Superfund, RCRA Corrective Action, and Underground Storage Tank Site, Office of Solid Waste and Emergency Response (OSWER), Directive 9200.4-17P, Final Draft, Washington, D.C., April 21, 1999.

Wiedemeier, T.H., Rifai, H.S., Newell, C.J., and Wilson, J.W. 1999. Natural Attenuation of Fuels and Chlorinated Solvents, John Wiley \& Sons, New York.

Wiedemeier, T. H., M.A. Swanson, D.E. Moutoux, E.K. Gordon, J.T. Wilson, B.H. Wilson, D.H. Kampbell, J.E. Hansen, and P. Haas., F. Chapelle. 1998. Technical Protocol for Evaluation Natural Attenuation of Chlorinated Solvents in Groundwater, U.S. Environmental Protection Agency, EPA/600R0128, Sept. 1998. 


\section{APPENDIX A -Technical Assistance Team Members}

\begin{tabular}{|l|l|l|}
\hline Name & Organization & Specialty \\
\hline Miles Denham & WSRC-SRTC & Geochemistry / Metals \\
\hline Carol Eddy-Dilek & WSRC-SRTC & $\begin{array}{l}\text { Geology, Environmental } \\
\text { Characterization }\end{array}$ \\
\hline Terry Hazen & $\begin{array}{l}\text { Lawrence Berkeley } \\
\text { National Laboratory }\end{array}$ & Microbiology \\
\hline Chuck Newell & Groundwater Services & $\begin{array}{l}\text { Monitored Natural } \\
\text { Attenuation, DNAPL } \\
\text { Characterization }\end{array}$ \\
\hline Brian Looney & WSRC-SRTC & $\begin{array}{l}\text { Characterization and } \\
\text { Remediation Technology }\end{array}$ \\
\hline Brian Riha & WSRC-SRTC & $\begin{array}{l}\text { Environmental } \\
\text { Characterization }\end{array}$ \\
\hline
\end{tabular}


This page was intentionally left blank 


\section{APPENDIX C - Technical Team Biographies}

Brian Looney. Dr. Looney is a fellow research engineer at the Savannah River Technology Center. In this position for the past 15 years, he has coordinated development and deployment of environmental characterization and clean-up technologies. Dr. Looney has successfully performed environmental projects on a wide range of topics. For example, he was principal investigator responsible for the first large scale application of horizontal drilling to environmental remediation. Other successful research efforts include: soil gas survey techniques for hazardous waste sites, barometric pumping for vadose zone clean up. gas phase nutrient addition to stimulate bioremediation, and various topics associated with modeling and risk assessment. Dr. Looney currently holds five U.S. and one foreign patent for environmental technologies. Most of these are licensed to environmental engineering companies and are in use throughout the U.S. Dr. Looney, in collaboration with others, contributed to recent field studies at the Mayak Site (a former nuclear production facility) in Russia. Recently, Dr. Looney co-edited the book "Vadose Zone Science and Technology Solutions". He also led the successful efforts to redefine the Subsurface Contaminants Focus Area technical program in terms of technical targets within which R\&D programs could be developed.

Terry Hazen. Dr. Hazen's area of specialty is environmental microbiology, especially as it relates to bioremediation. His current research is focused on aerobic bioremediation of landfills, PAH contaminated soil, solvent contaminated soil and groundwater, and actinide biogeochemistry. Since early 1998, Dr. Hazen has been Head of the Microbial Ecology and Environmental Engineering Department and Lead Scientist for the Environmental Remediation Technology Program in the LBNL Earth Sciences Division. Since September 1999 he has also been head of the Center for Environmental Biotechnology. He is a fellow of the American Academy of Microbiology and has authored more than 151 scientific publications, not including more than 390 abstracts and chapters in several books. He has also given more than 670 scientific presentations, $75 \%$ of them invited. Dr. Hazen received the 1995 R\&D 100 Award, 1996 R\&D 100 Award, and the 1996 Federal Laboratory Consortium Excellence in Technology Transfer for bioremediation technologies. He has patents on 5 bioremediation processes that are being used in 15 states; these technologies have been licensed to more than 30 companies. Dr. Hazen has acted as an expert reviewer for 25 different scientific journals and 14 federal research granting agencies. He has supervised and consulted on the implementation of bioremediation at more than 50 sites in several countries. He is currently the LBNL representative to the DOE EM50 Strategic Lab Council, the DOE Natural and Accelerated Bioremediation Research Program Field Research Center, the EM50 Subsurface Contaminant Focus Area Lead Lab POC, and the EM50 lead for LBNL. He was recently appointed to the United Nations Global Water Quality Task Force, one of only two US scientists. 
Miles Denham. Dr Denham is a Fellow Scientist at the U.S. Department of Energy Savannah River Technology Center (SRTC). In this position for the past 11 years he has directed research involving metal contaminated groundwater and soil. Particular interests include reactions associated with natural attenuation of metals and radionuclides and the importance of minor minerals in these reactions. Research at SRTC has included mercury speciation and remediation in groundwater, remediation of metals in acidic groundwater, radium migration in groundwater associated with a coal storage site, and geochemical and microbiological effects of injection of Fenton's Reagent into an aquifer for in-situ destruction of DNAPL. In the past 3 years Dr. Denham has collaborated with Clarkson University on a project investigating influence of soil properties on DNAPL distribution in the subsurface (EMSP Project No. 70035). Recent collaborations with other SRS researchers include investigating innovative methods of mercury remediation and metal stabilization. He served on the Peer Review Panel assessing the Uranium in Soils Integrated Demonstration for the D.O.E. Office of Science and Technology. Dr. Denham received his Ph.D. from Texas A\&M University in 1992 and, before that, his M.S. from the State University of New York at Stony Brook.

Charles J. Newell. Dr. Newell is a Vice President of Groundwater Services, Inc. He is a Diplomate in the American Academy of Environmental Engineers and is an Adjunct Professor at Rice University. He has co-authored three EPA publications, five environmental decision support software systems, numerous technical articles, and two books: Natural Attenuation of Fuels and Chlorinated Solvents and Ground Water Contamination: Transport and Remediation. His professional expertise includes site characterization, groundwater modeling, non-aqueous phase liquids, risk assessment, natural attenuation, bioremediation, non-point source studies, software development, and long-term monitoring projects. He served on the EPA's DNAPL Workshop in 1991 and was one of four speakers who presented the EPA's Seminar on Characterizing and Remediating DNAPL at Hazardous Waste Sites in 10 cities in 1993. He has also served as a nationwide Risk-Based Corrective Action (RCBA) trainer for the American Society for Testing and Materials (ASTM). Dr. Newell has been awarded the Hanson Excellence of Presentation Award by the American Association of Petroleum Geologists, the Outstanding Presentation Award by the American Institute of Chemical Engineers, and the 2001 Wesley W. Horner Award by the American Society of Civil Engineers (for the paper, "Modeling Natural Attenuation of Fuels with BIOPLUME III").

\section{Brian Riha}

Mr. Riha is a principal investigator at the Savannah River Technology Center where he performs applied research and development of environmental characterization and remediation technologies and strategies. His research involved development, field-testing and implementation of characterization and remediation methods with emphasis on DNAPL characterization, subsurface access and installation methods. He has an M.S. in environmental engineering from Clemson University, and a M.S. in civil engineering from Texas Tech University. 